\title{
32. DARK-LIGHT RHYTHMS IN THE SEDIMENTS OF THE JAPAN SEA: PRELIMINARY RESULTS FROM SITE 798, WITH SOME ADDITIONAL RESULTS FROM SITES 797 AND 7991
}

\author{
Karl B. Föllmi, ${ }^{2}$ Adrian Cramp, ${ }^{3}$ Karl E. Föllmi ${ }^{4}$ Joanne M. Alexandrovich, ${ }^{5}$ Charlotte Brunner, ${ }^{6}$ Lloyd H. Burckle, ${ }^{5}$ Martin \\ Casey, ${ }^{2}$ Peter deMenocal, ${ }^{5}$ Robert B. Dunbar, ${ }^{7}$ Kurt A. Grimm, ${ }^{8}$ Peter Holler, ${ }^{9}$ James C. Ingle, Jr., ${ }^{10}$ Tara Kheradyar, ${ }^{10}$ James \\ McEvoy, ${ }^{11}$ David C. Nobes, ${ }^{12}$ Ruediger Stein, ${ }^{13}$ Ryuji Tada, ${ }^{14}$ Marta T. von Breymann, ${ }^{15}$ and Lisa D. White ${ }^{8}$
}

\begin{abstract}
Ocean Drilling Program Legs 127 and 128 in the Japan Sea have revealed the existence of numerous dark-light rhythms of remarkable consistency in sediments of late Miocene, latest Pliocene, and especially Pleistocene age. Light-colored units within these rhythms are massive or bioturbated, consist of diatomaceous clays, silty clays, or nannofossil-rich clays, and are generally poor in organic matter. Dark-colored units are homogeneous, laminated, or thinly bedded and include substantial amounts of biogenic material such as well-preserved diatoms, planktonic foraminifers, calcareous nannofossils, and organic matter (maximum $7.4 \mathrm{wt} \%$ ).

The dark-light rhythms show a similar geometrical pattern on three different scales: First-order rhythms consist of a cluster dominated by dark-colored units followed by a cluster dominated by light-colored units $(3-5 \mathrm{~m})$. Spectral analysis of a gray-value time series suggests that the frequencies of the first-order rhythms in sediments of latest Pliocene and Pleistocene age correlate to the obliquity and the eccentricity cycles. The second-order dark-light rhythms include a light and a dark-colored unit $(10-160 \mathrm{~cm})$. They were formed in time spans of several hundred to several ten thousand years, with variance centering around 10,500 yr. This frequency may correspond to half the precessional cycle. Third-order rhythms appear as laminated or thinly bedded dark-light couplets $(2-15 \mathrm{~mm})$ within the dark-colored units of the second-order rhythms and may represent annual frequencies.

In interpreting the rhythms, we have to take into account that (1) the occurrence of the first- and second-order rhythms is not necessarily restricted to glacial or interglacial periods as is shown by preliminary stable-isotope analysis and comparison with the published $\delta^{18} \mathrm{O}$ record; (2) they appear to be Milankovitch-controlled; and (3) a significant number of the rhythms are sharply bounded. The origin of the dark-light rhythms is probably related to variations in monsoonal activity in the Japan Sea, which show annual frequencies, but also operates in phase with the orbital cycles.
\end{abstract}

\section{INTRODUCTION}

The present-day Japan Sea is characterized by oceanic depths (maximum water depth of $3742 \mathrm{~m}$ ) and a continental periphery cut by four shallow-marine straits: the Tsushima, Tsugaru, Soya, and Tartar straits, with maximum water depths of $140,130,55$, and $12 \mathrm{~m}$ below sea level (mbsl) respectively (Fig. 1). In spite of this silled configuration, waters of the Japan Sea are very well mixed and ventilated, with levels of dissolved oxygen exceeding $5.0 \mathrm{~mL} / \mathrm{L}$ at all depths (Niino et al., 1969; Matoba, 1984). Furthermore, the depth distribution of salinity and water temperature is exceptionally uniform below $300 \mathrm{mbsl}$ (approximately $34.07 \%$ oo and less than $0.3^{\circ} \mathrm{C}$; Matoba, 1984; Kobayashi, 1985). The intense convection of the Japan

${ }^{1}$ Pisciotto, K. A., Ingle, J. C., Jr., von Breymann, M. T., Barron, J., et al., 1992. Proc. ODP, Sci. Results, 127/128, Pt. 1: College Station, TX (Ocean Drilling Program).

${ }^{2}$ Geological Institute, ETH Center, CH-8092 Zurich, Switzerland.

${ }^{3}$ Department of Geology, University of Wales, PO Box 914, Cardiff CF1 3YE, United Kingdom.

${ }^{4}$ Lieven de Keylaan 12, NL-2101 VE Heemstede, Netherlands.

5 Lamont-Doherty Geological Observatory, Columbia University, Palisades, NY 10964, U.S.A.

${ }^{6}$ Center for Marine Science, University of Southern Mississippi, Bay St. Louis, MI 39529, U.S.A.

${ }^{7}$ Department of Geology, Rice University, PO Box 1892, Houston, TX 77251, U.S.A.

${ }^{8}$ Earth Sciences Board, University of California, Santa Cruz, CA 95064, U.S.A.

${ }^{9}$ Geological Institute, University of Kiel, D-2300 Kiel, Federal Republic of Germany.

${ }^{10}$ Department of Geology, Stanford University, Stanford, CA 94305, U.S.A.

"School of Ocean Sciences, University College of North Wales, Anglesey LL59 5EY. United Kingdom. -

${ }^{12}$ Department of Earth Sciences, University of Waterloo, Waterloo, Ontario N2L 3GI, Canada.

${ }^{13}$ Alfred-Wegener Institute, D-2850 Bremerhaven, Federal Republic of Germany.

${ }_{14}^{14}$ Geological Institute, University of Tokyo, Tokyo-113, Japan.

${ }^{15}$ GEOMAR, Wischhofstrasse 1-3, Gebaude 12, D-2300 Kiel 14, Federal Republic of Germany.
Sea water masses is induced and maintained by the inflow of the warm and saline Tsushima current, a branch of the Kuroshio, through the Tsushima Strait, and chilling of northern surface waters during Siberian winters. Warm waters of the Tsushima current leave the Japan Sea through the Tsugaru Strait and partly through the Soya Strait. The inflow of Pacific intermediate and deep waters is prevented by the shallow sills, and Japan Sea deep waters are exclusively derived from its own surface waters by intense winter cooling along the Siberian coast, and consequent southward migration and sinking to deeper parts of the Japan Sea (Liman current system).

The silled configuration of the Japan Sea renders its mode of oceanographic operation extremely sensitive to changes in sea level and therefore to changes in current regimes resulting from the emergence of sills, as well as to the active tectonic regime (cf. Tamaki, 1988). Furthermore, water circulation in this isolated basin may also depend on the marked change from warm and humid summers controlled by southern monsoonal winds (typhoons) to cold and dry winters characterized by northern Siberian winds. Hence, it is predictable that, as a response to past changes in climatic and tectonic conditions, substantial paleoceanographic changes have occurred in the Japan Sea. In turn, these events may be documented in the sedimentary column. Indeed, piston cores collected from a closely spaced network spanning the Japan Sea show that sediments, especially of latest Pleistocene age, are marked by extreme facies changes due to variations in terrigenous and biogenic fluxes (Ujiié and Ichikura, 1973; Ichikura and Ujiié, 1976; Honza, 1979; Arai et al., 1981; Oba, 1983; Chough, 1984; Matoba, 1984; Kobayashi, 1985; Oba et al., 1991).

One of the most intriguing results of the 1989 Ocean Drilling Program campaign in the Japan Sea (Legs 127 and 128; Fig. 1) is the recognition of the spatial and temporal persistence, and remarkable uniformity of such sedimentary variations over large intervals of the drilled sedimentary sections (Tamaki, Pisciotto, Allan, et al., 1990; Ingle, Suyehiro, von Breymann, et al., 1990; Leg 127 and Leg 128 


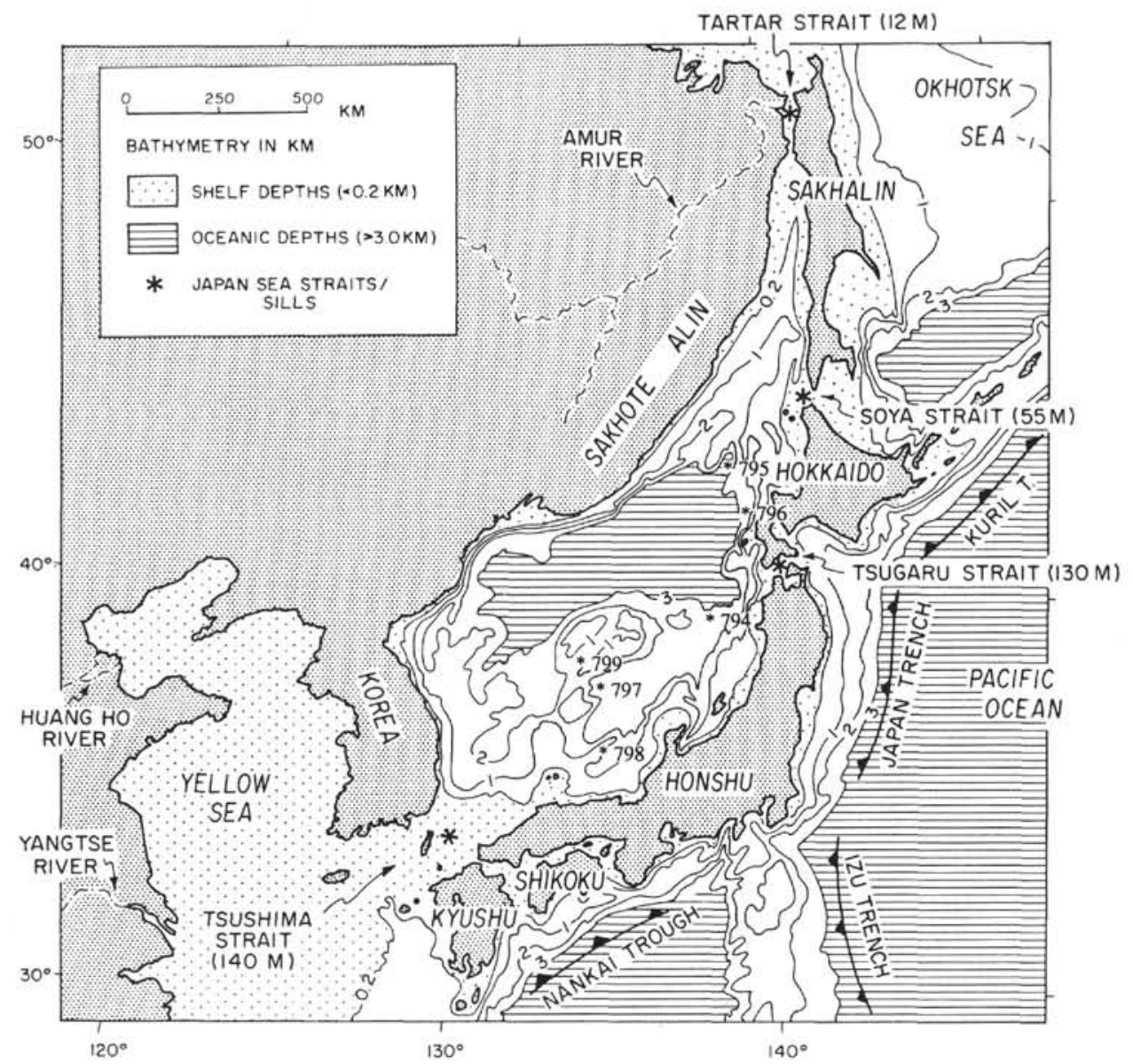

Figure 1. Map of the Japan Sea, showing Ocean Drilling Program Leg 127 Sites 794-797 and Leg 128 Sites 794, 798 , and 799. Site 794 was occupied during both legs. Note the near-oceanic depth of the northern area of the Japan Sea and the contrastingly shallow sills and straits connecting the Sea of Japan and the western Pacific. From Ingle, Suyehiro, von Breymann, et al. (1990).

Scientific Parties 1990; Leg 127 Scientific Party, 1989; Leg 128 Scientific Party, 1990; Föllmi et al., 1990; Tada et al., this volume). These rhythms occur in the upper Miocene, uppermost Pliocene, and Pleistocene sediments; however, they are most prominent and persistent in sediments of late Pleistocene age (Figs. 2 and 3).

These distinct sedimentary alternations are characterized by darkcolored, homogeneous or laminated units rich in biogenic debris, and light-colored, homogeneous or bioturbated units rich in terrigenous silt and clay (Figs. 2-5). The rhythms reflect high-frequency changes in the depositional environment of the Japan Sea, which in turn indicate that shifts in the oceanographic operational mode of the Japan Sea were common and rapid, especially in the Pleistocene, with periodicities ranging between one hundred thousand years and markedly less than one thousand year, which is distinctly shorter than those of the Milankovitch frequency band (e.g., Imbrie et al., 1984).

Site 797 is located in the southwestern Yamato Basin, near the slope of the Yamato Rise and the Kita-Oki Bank, in a water depth of $2862.2 \mathrm{mbsl}$ (Tamaki, Pisciotto, Allan, et al., 1990). The drilled succession at Site 797 consists predominantly of hemipelagic, biosiliceous, and silty claystones. The oldest sediments obtained have been assigned with an early Miocene age. They are interstratified with basalts and include significant detrital and volcaniclastic horizons.

Site 798 is situated in a small, sediment-filled depression on top of a rifted continental fragment, which presently stands out as the isolated Oki Ridge in the southeastern part of the Japan Sea (Tamaki,
1988; Ingle, Suyehiro, von Breymann, et al., 1990). The surface of the Oki Ridge is a well-pronounced relief, with the shallowest parts less than $300 \mathrm{mbsl}$. The site itself has a water depth of $902 \mathrm{mbsl}$, which is well above the present local carbonate compensation depth at approximately $2300 \mathrm{mbsl}$ (Ichikura and Ujiié, 1976). Because the Oki Ridge is presently at a relative elevation of $2000 \mathrm{~m}$ above the abysmal plain, it is bypassed by bed-load transported detritus. Sediments at the site are primarily hemipelagic, comprising mostly diatomaceous clays with some wind-blown detritus. Pre-Pleistocene sediments contain coarse detrital quartz grains, which were deposited before this fragment of continental crust was uplifted (Ingle, Suyehiro, von Breymann, et al., 1990). The oldest sediments recovered at Site 798 are at least early Pliocene in age and may be as old as latest Miocene (L. Burckle, pers. comm., 1990).

Site 799 is located in the northeast-trending Kita-Yamato Trough, at a depth of $2073 \mathrm{mbsl}$ (Fig. 1). This graben structure is flanked to the northwest by the Kita-Yamato Bank (shallowest point at $458 \mathrm{mbsl}$ ) and to the southeast by the Yamato Bank (shallowest point at $236 \mathrm{mbsl}$ ). These prominent and isolated elevations are composed of fault-bounded volcanic and granitic rocks (Tamaki, 1988; Barash, 1986; Kobayashi, 1985; Honza, 1979). The sedimentary sequence recovered at Site 799 consists predominantly of hemipelagic biosiliceous-rich sediments, but also includes gravity-flow deposits derived from the flanking highs. The oldest sediments recovered at Site 799 are early middle Miocene in age (Hamano et al., this volume). 


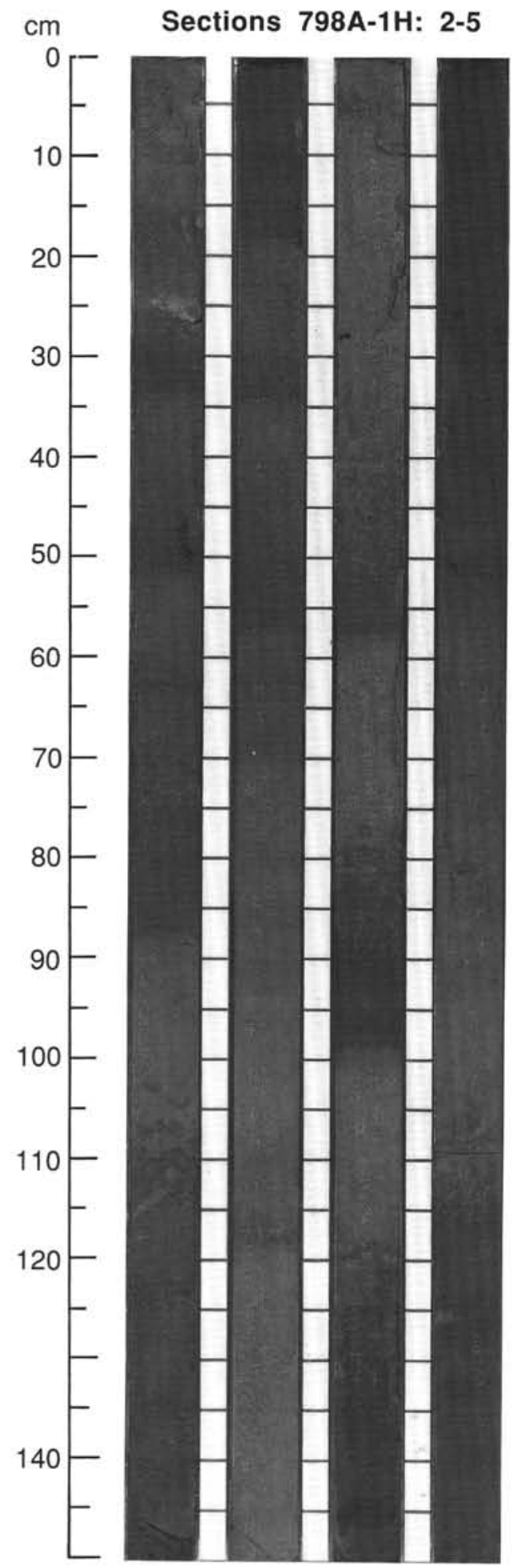

Sections 795A-7H: 4-6

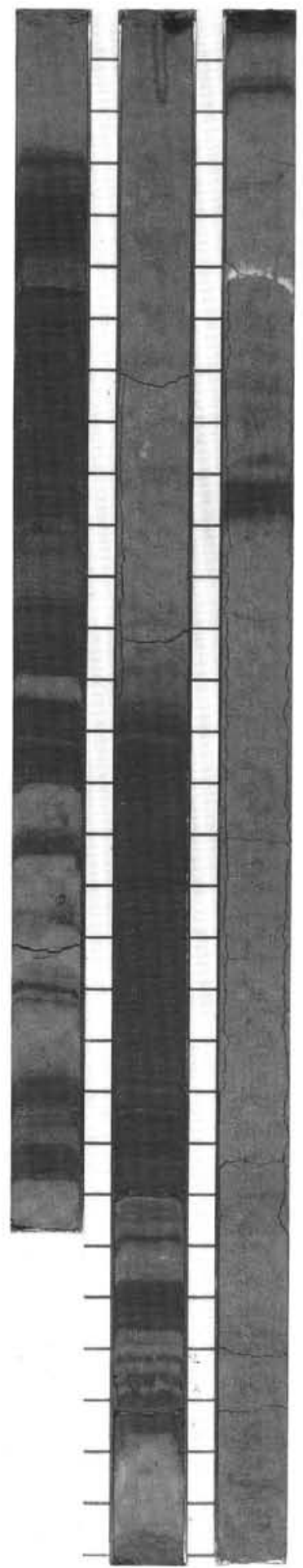

Sections 799A-11H: 3-6

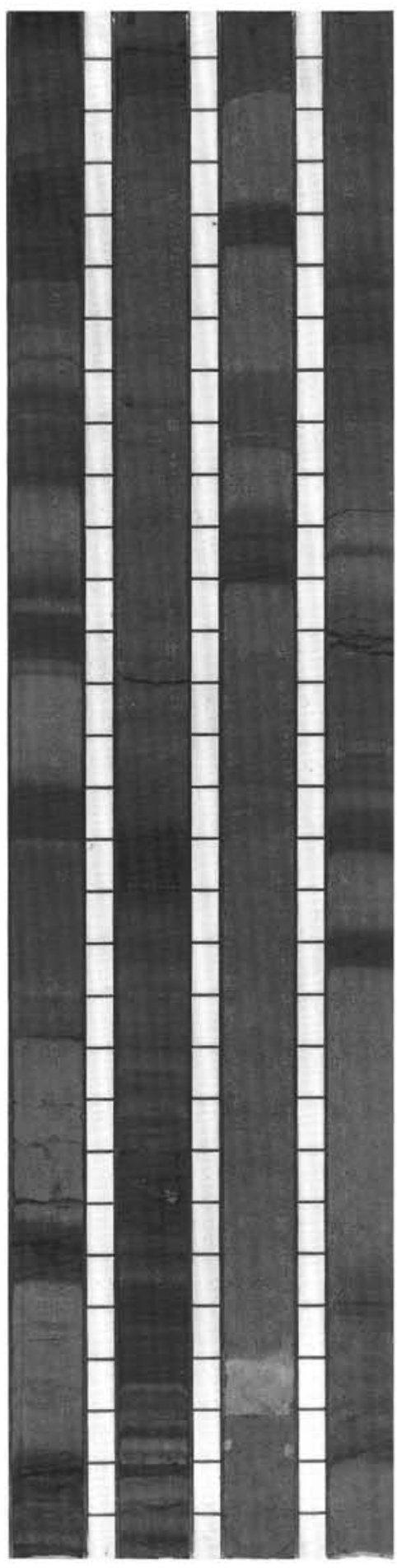

Figure 2. Pleistocene short-frequency dark-light rhythms at Sites 795, 798, and 799. Sections 128-798A-IH-2 to 128-798A-1H-5 are of latest Pleistocene age, Sections 127-798A-7H-4 to 127-795A-7H-6 of late early Pleistocene age, and Sections 128-799A-11H-3 to 128-799A-11H-6 of late early Pleistocene age. 
$\mathrm{cm}$

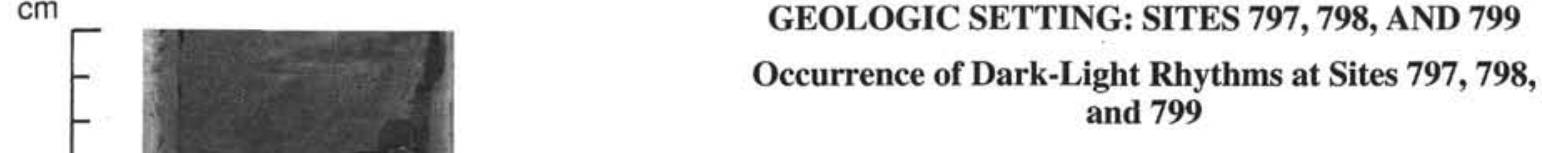

Prominent dark-light rhythms are present on three scales at Sites 797, 798, and 799 (Oba et al., 1991; Föllmi et al., 1990; Tamaki, Pisciotto, Allan, et al., 1990: Ingle, Suyehiro, von Breymann, et al., 1990, Tada et al., this volume). At Site 797, these rhythms are common between 0 and $60 \mathrm{~m}$ below seafloor ( $\mathrm{mbsf}$ ) and occur sporadically to approximately $115 \mathrm{mbsf}$. At Site 798 , they dominate the interval between 0 and approximately $140 \mathrm{mbsf}$ and are less common to approximately $300 \mathrm{mbsf}$; and at Site 799 , they occur commonly between 0 and approximately $110 \mathrm{mbsf}$ and sporadically to $170 \mathrm{mbsf}$. The boundaries between common and sporadic occurrence of the rhythms of the different sites correlate remarkably well and correspond to the middle part of the normal-polarity interval between the Jaramillo and Olduvai reversed intervals (= approximately $1.25 \mathrm{~m} . \mathrm{y}$. ago). The first occurrences of dark-light rhythms in this part of the sedimentary sequence are also correlatable between the sites and correspond to the upper limit of the Gauss reversed interval (approximately 2.4 m.y. ago). These findings are in full accordance with the results from Sites 794 and 795 (Leg 127; Tada et al., this volume).

A second occurrence of dark-light rhythms at Site 797 is located between approximately 245 and 325 mbsf. This interval is biostratigraphically dated as the younger part of the late Miocene (Tamaki, Pisciotto, Allan, et al., 1990). At Site 798, a correlative interval of dark-light rhythms occurs in the sedimentary sequence below approximately $430 \mathrm{mbsf}$. Dating is still unclear in this portion of the recovered sedimentary column. The preserved diatom flora points to a latest Miocene age, whereas the magnetostratigraphy obtained places this sequence in the earliest Pliocene (Hamano et al., this volume). At Site 799, correlative dark-light rhythms are documented between 350 and $650 \mathrm{mbsf}$. This interval corresponds to the upper limit of Chron 5 to middle upper part of Chron 11, and thus spans the entire late Miocene.

\section{Dark-Light Rhythms at Site 798}

One of the great advantages of Site 798, besides being an excellent site for the recovery of a pelagic sequence undisturbed by coarse terrigenous input, is the presence of three different holes cored by advanced hydraulic piston coring (APC) techniques. The APC holes are situated along a north-south axis with intervening distances of approximately $20 \mathrm{~m}$ (Ingle, Suyehiro, von Breymann, et al., 1990). The three different holes allow for a precise correlation of the upper 150 mbsf (Fig. 6). This correlation is based on the patterns in which the dark-light rhythms occur, as well as the numerous ash layers. They allow for a reliable correlation of Cores 1-13 of Holes 798 A-798C. Cores 14 and 15 are correlated in a best-fit approach, because of the absence of corresponding APC cores from Hole 798C, which was terminated after Core 13, at a depth of 120 mbsf. From these cores, we have chosen the best preserved segments and fitted those into a synthetic succession which completely covers the sedimentary record of Site 798 for the last 1.26 m.y., without recognized hiatuses (Fig. 6; the segments and their correlative boundaries are indicated and each dark interval is consecutively numbered: 225 dark intervals for the last 1.26 m.y.). The following observations were made during the correlation procedure:

1. A slump interval separating two prominent ash layers is present in Section 128-798C-7H-4. These ash layers are probably doubled from one ash layer that correlates with an ash layer in Sections 128-798A-6H-7, 59-67 cm, and 128-798B-7H-1, 45-56 cm.

2. Sections $128-798 \mathrm{~B}-10 \mathrm{H}-4$ and $128-798 \mathrm{~B}-10 \mathrm{H}-7$ are exchanged in the core photograph (in Ingle, Suyehiro, von Breymann, et al., 1990), and can only be correlated to other holes in original position,

Figure 3. A dark-light rhythm of late Miocene age (Section 128-799B-5R-1). 


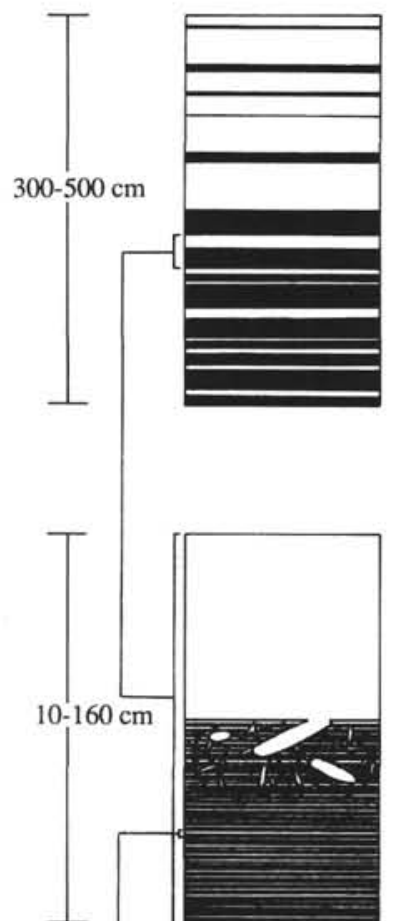

\section{First-order rhythm}

Cluster dominated by light-colored units

Cluster dominated by dark-colored units

\section{Second-order rhythm}

Massive or bioturbated, light-colored unit

-rich in fine-grained terrigenous detritus

-dominance of benthic foraminifera

-poor in organic matter

-burrows (Chondrites, Planolites) extending in subjacent unit

Massive or laminated, dark-colored unit

-rich in biogenic detritus

-dominance of planktonic foraminifera

-rich in organic matter

abrupt or gradational basal contact

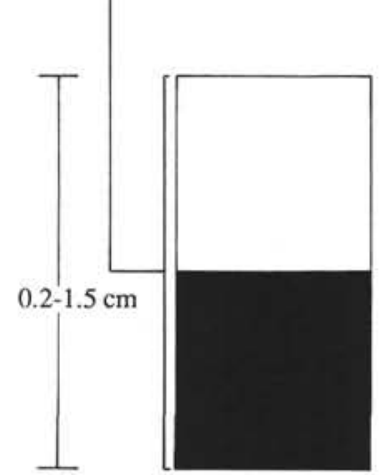

\section{Third-order rhythm}

Light-colored lamina, rich in terrigenous detritus

Dark-colored lamina, rich in biogenic detritus

Figure 4. Characterization of dark-light rhythms at Site 798 (cf. Fig. 2). The dark-light rhythms exhibit a similar geometrical pattern on three different scales. Clusters of dark units and clusters of light units correspond to obliquity and eccentricity frequencies (first-order rhythms; Ingle, Suyehiro, von Breymann, et al., 1990; deMenocal et al., this volume). The dark-light rhythms have a frequency of over 10,000 to less than $1000 \mathrm{yr}$ (second-order rhythms) and the dark-light laminae and thin beds have a frequency of one to several years (third-order rhythms).

which confirms earlier shipboard suspicions based on the preliminary magnetostratigraphic results.

3. Large portions of sediment may be missing between each pair of cores, with a tendency of more sediment missing downcore (Table 1).

The large amounts of sediment missing between most cores is probably due to gas expansion of the sediments and consequent loss during retrieval of the cores (cf. Ingle, Suyehiro, von Breymann, et al., 1990). As a consequence, we obtain a significant increase in the thickness of the decompacted and degassed sediments compiled in the synthetic sequence, in comparison to the compacted thicknesses approximated by drilling-depths (Fig. 7). This is of importance for the calculation of sediment-accumulation rates and especially for the correlation of the Site 798 characteristics with other sites (see the following).

\section{Time Model and Sediment Accumulation Rates for Site 798}

For an age-depth correlation, we employed the high-quality and unambiguous magnetostratigraphic results of the upper Pleistocene segment of Site 798 (Hamano et al., this volume). The data used here for Hole 128-798B are the following:

1. The youngest retrieved sediments in Hole $798 \mathrm{C}$ are considered to be modern, based on their stable-isotope signatures (Dunbar et al., this volume).

2. Brunhes/Matuyama boundary ( 0.73 m.y. ago): $68 \mathrm{mbsf}$ drill depth $=79.9 \mathrm{mbsf}$ in the synthetic correlation sequence of decompacted sediments (Fig. 7). Note that this boundary is correlated with a prominent flexure in the magnetic intensity rather than with the shipboard-derived inclination (J. Wippern and K. Krumsiek, pers. comm., 1991). 
Table 1. Estimates of missing sediment between each Site 798 APC-derived core. Note: Estimates are based on correlation of all Site 798 APC cores (Fig. 7).

\begin{tabular}{cc}
\hline Cores & Sediment missing $(\mathrm{m})$ \\
\hline $128-798 \mathrm{~A}$ & \\
& \\
$1 \mathrm{H}-2 \mathrm{H}$ & 0.7 \\
$2 \mathrm{H}-3 \mathrm{H}$ & 4.5 \\
$3 \mathrm{H}-4 \mathrm{H}$ & 1.2 \\
$4 \mathrm{H}-5 \mathrm{H}$ & 5.0 \\
$5 \mathrm{H}-6 \mathrm{H}$ & 2.5 \\
$6 \mathrm{H}-7 \mathrm{H}$ & 3.0 \\
$7 \mathrm{H}-8 \mathrm{H}$ & 2.5 \\
$8 \mathrm{H}-9 \mathrm{H}$ & 3.6 \\
$9 \mathrm{H}-10 \mathrm{H}$ & 0.9 \\
$10 \mathrm{H}-11 \mathrm{H}$ & 3.9 \\
$11 \mathrm{H}-12 \mathrm{H}$ & 0 \\
$12 \mathrm{H}-13 \mathrm{H}$ & 4.0 \\
$13 \mathrm{H}-14 \mathrm{H}$ & 6.1 \\
$14 \mathrm{H}-15 \mathrm{H}$ & 2.2 \\
\end{tabular}

128-798B

$\begin{array}{ll}1 \mathrm{H}-2 \mathrm{H} & 0 \\ 2 \mathrm{H}-3 \mathrm{H} & 1.0 \\ 3 \mathrm{H}-4 \mathrm{H} & 0 \\ 4 \mathrm{H}-5 \mathrm{H} & 2.0 \\ 5 \mathrm{H}-6 \mathrm{H} & 1.9 \\ 6 \mathrm{H}-7 \mathrm{H} & 2.3 \\ 7 \mathrm{H}-8 \mathrm{H} & 1.7 \\ 8 \mathrm{H}-9 \mathrm{H} & 1.2 \\ 9 \mathrm{H}-10 \mathrm{H} & 2.2 \\ 10 \mathrm{H}-11 \mathrm{H} & 3.5 \\ 11 \mathrm{H}-12 \mathrm{H} & 4.0 \\ 12 \mathrm{H}-13 \mathrm{H} & 1.1 \\ 13 \mathrm{H}-14 \mathrm{H} & 1.4 \\ 14 \mathrm{H}-15 \mathrm{H} & 6.8\end{array}$

$128-798 \mathrm{C}$

\begin{tabular}{cl}
$1 \mathrm{H}-2 \mathrm{H}$ & 0.7 \\
$2 \mathrm{H}-3 \mathrm{H}$ & 0 \\
$3 \mathrm{H}-4 \mathrm{H}$ & 0 \\
$4 \mathrm{H}-5 \mathrm{H}$ & 0 \\
$5 \mathrm{H}-6 \mathrm{H}$ & 2.0 \\
$6 \mathrm{H}-7 \mathrm{H}$ & 1.0 \\
$7 \mathrm{H}-8 \mathrm{H}$ & 2.8 \\
$8 \mathrm{H}-9 \mathrm{H}$ & 2.0 \\
$9 \mathrm{H}-10 \mathrm{H}$ & 2.8 \\
$10 \mathrm{H}-11 \mathrm{H}$ & 2.1 \\
$11 \mathrm{H}-12 \mathrm{H}$ & 3.3 \\
$12 \mathrm{H}-13 \mathrm{H}$ & 1.6 \\
\hline
\end{tabular}

3. Upper limit Jaramillo reversed interval (0.9 m.y. ago): $90.0 \mathrm{mbsf}$ drill depth $=108 \mathrm{mbsf}$ in compiled synthetic sequence (Fig. 7).

4. Lower limit Jaramillo reversed interval ( $0.98 \mathrm{~m} . \mathrm{y}$. ago): $99.5 \mathrm{mbsf}$ drill depth $=122.1 \mathrm{mbsf}$ in compiled synthetic sequence (Fig. 7).

5. Upper limit Olduvai reversed interval (1.66 m.y. ago): $190 \mathrm{mbsf}$ drill depth; in order to convert this depth to a theoretical depth from the compiled synthetic sequence (which ends at $176 \mathrm{mbsf}$ ), the drilled depth was plotted against the decompacted depth from the retrieved cores using the depths of the above fixed points and extrapolated down to 190 mbsf with a best-fit polynomial (Fig. 7). The corresponding theoretical depth value thus obtained is $252 \mathrm{mbsf}$.

Between these fixed points, constant sediment accumulation rates are assumed. Based upon this time model, the following linear sediment accumulation rates were calculated:

1. 0-0.73 m.y. ago, $10.9 \mathrm{~cm} / 1000 \mathrm{yr}$.

2. $0.73-0.9$ m.y. ago, $16.6 \mathrm{~cm} / 1000 \mathrm{yr}$.
3. $0.9-0.98 \mathrm{~m} . \mathrm{y}$. ago, $17.5 \mathrm{~cm} / 1000 \mathrm{yr}$.

4. $0.98-1.66$ m.y. ago, $19.1 \mathrm{~cm} / 1000 \mathrm{yr}$.

These rates are valid for the thicknesses of the decompacted sediments obtained by correlation of the Site 798 APC cores and corrected for section loss during coring.

\section{Similarity in Geometry of Different Dark-Light Rhythm Hierarchies}

The geometry of the dark-light rhythms at Site 798 is superimposed by clusters. These clusters are particularly evident in the natural gamma-ray and aluminum logs (Ingle, Suyehiro, von Breymann et al., 1990; deMenocal et al., this volume). Each cluster is either dominated by dark- or light-colored units and the clusters reach thicknesses of approximately 3-5 m (Fig. 4). At the other, basinal sites (Sites 794, 795, 797, and 799), clusters are present as well; however, their clear recognition is complicated by the intercalation of gravity-flow deposits such as slumps, sediment slides, and turbidites. The clusters are classified as first-order rhythms.

The dark-light rhythms sensu stricto, with thicknesses of 10-160 $\mathrm{cm}$, are considered second-order rhythms (Fig. 4). Dark-light laminae couplets, which commonly occur within the dark-colored units of the second-order rhythms at all sites, are classified as third-order rhythms (0.2-1.5 cm; Fig. 4).

The dark-light rhythms, therefore, exhibit a similar pattern on three different scales (self-similarity). This reflects the possibility that the mechanism responsible for the formation of these distinct alternations is identical on all three levels, and operated in three different, superimposed time frequencies.

\section{General Structure and Composition of Dark- Colored Units}

The base of the dark-colored unit of the second-order rhythms is usually well defined, and, in a significant part of the occurrences, distinctly sharp. Erosional truncation, however, is not evident in most cases. The basal contact may also be transitional (Fig. 2).

Dark units are either homogeneous or thickly laminated to thinly bedded (i.e., composed of third-order dark-light rhythms) (Figs. 2-5). The third-order rhythmic couplets exhibit dark-colored lower laminae rich in biogenic debris with a sharp base, and light-colored upper laminae rich in fine-grained terrigenous detritus. In this manner, the third-order rhythms within the dark interval resemble the overall rhythmic bedding in the second-order rhythms on a millimeter scale (see the following).

Shipboard and preliminary shorebased analyses show that the dark-colored units and laminae are enriched in biologically derived material and impoverished in silt-size terrigenous detritus, in comparison with the light-colored counterparts. Diatom skeletons, planktonic foraminifers (e.g., Globigerina bulloides), monaxon sponge spicules, and calcareous nannoplankton are abundant in the dark units. Thin laminae (approximately $1.5 \mathrm{~mm}$ ) occur locally in the dark units, which are matrix-poor and highly enriched in Globigerina, Chaetoceras resting spores or sponge spicules (cf. Grimm and Kheradyar, this volume). Moreover, the dark-colored units are enriched in organic matter, and contain up to $7.4 \mathrm{wt} \%$ total organic carbon (Tamaki, Pisciotto, Allan, et al., 1990; Ingle, Suyehiro, von Breymann, et al., 1990). Preliminary organic geochemical analyses indicate that the source of the organic matter is varied and may have been either marine, mixed, or terrestrial (Stein, 1991).

At Site 798 on Oki Ridge, the upper part of the dark-colored intervals is generally burrowed. At all other, basinal sites, burrows in these intervals occur only sporadically. The presence or absence of bioturbation may be related to the difference in depth (e.g., Ichikura 


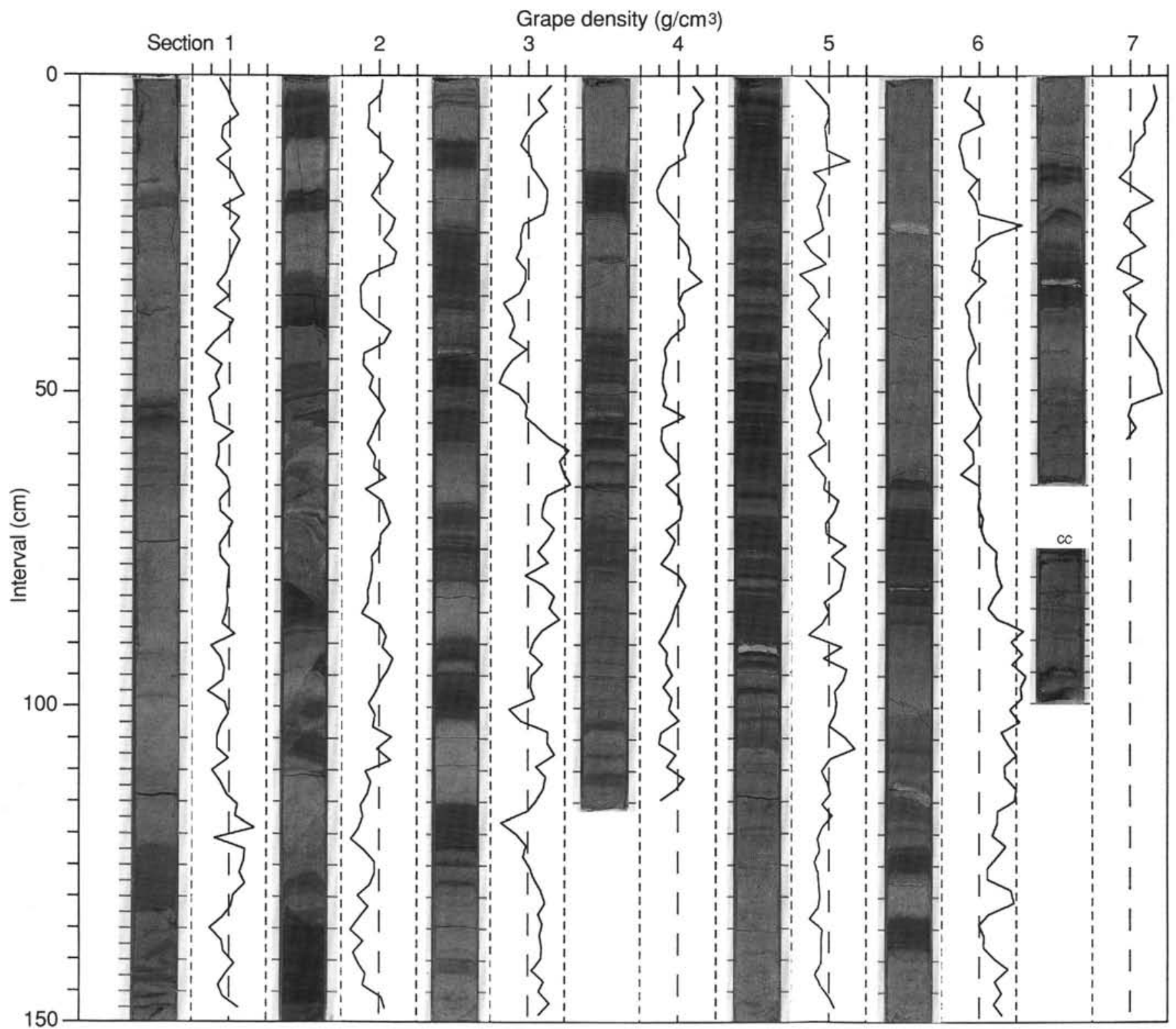

Figure 5. Dark-light rhythms and GRAPE-density measures in Core 127-797B-6H, 43.9-53.4 mbsf (lower Pleistocene).

and Ujiié, 1976). The burrows are filled with light-colored sediments derived from the superjacent light-colored unit (Figs. 2-4). The most common type of burrows measure 2-4 mm in diameter, show downward-directed bifurcations, and were attributed to Chondrites. Commonly, Chondrites burrows are crosscut by a second generation of large, subhorizontal to vertical burrows (maximum diameter is $2 \mathrm{~cm}$ ), which remain unidentified (some resemble Planolites and Thalassinoides).

\section{General Structure and Composition of Light- Colored Units}

The light-colored units in the second-order rhythms are either massive or bioturbated. Recognizable burrows are mostly limited to the lower portions of the light-colored units and clearly connected to the burrows in the top intervals of the dark-colored units. The bases of the light-colored units are in some cases transitional and obliterated by extensive burrowing, whereas in other cases they appear sharp and well defined.
In comparison to the dark-colored units, the light-colored units show an enrichment in terrigenous detritus: They consist of diatomaceous clays, silty clays, or nannofossil-rich clays. Diatoms are not as well preserved as in the dark units; in some cases they are highly fragmented. Benthic foraminifers prevail, whereas planktonic foraminifers are rare.

\section{ANALYSES OF SELECTED DARK-LIGHT RHYTHMS}

As a nucleus and test case for future research work, we selected two typical second-order dark-light rhythms from the Pleistocene: one from the ridge-top Site 798 and one from the basinal Site 797 and performed a series of physical, geochemical, and paleontologic analyses. The selected cores have a similar age (approximately 920,000 (Site 798) and 940,000 yr ago (Site 797), respectively).

In addition, we selected five well defined, second-order, dark-light rhythms from the Pleistocene of Hole 128-798C for XRF analyses of major and trace elements, and stable isotope analyses. Furthermore, 


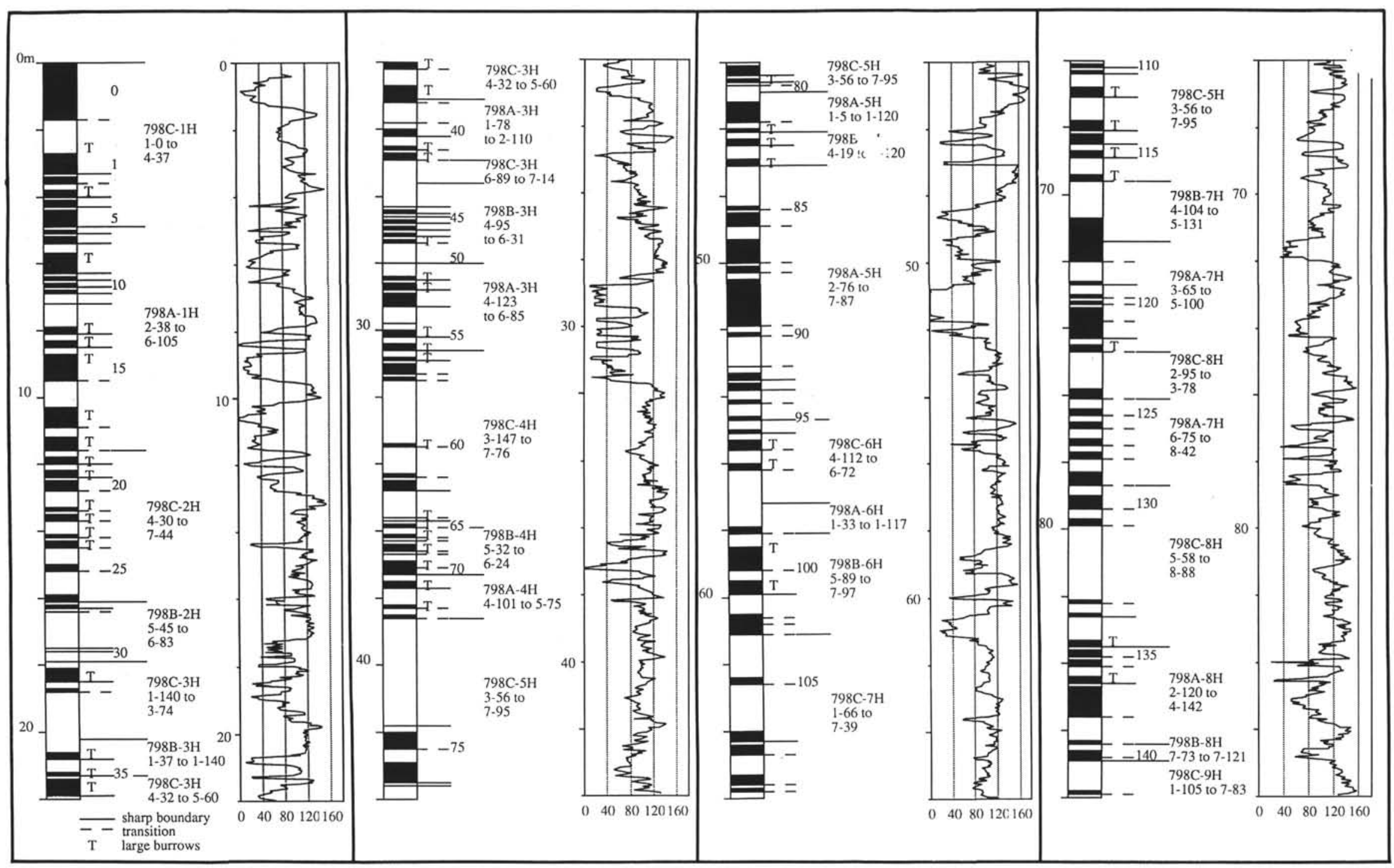

Figure 6. Compilation of dark-light rhythms at Site 798, based on the visual inspection of photographs of APC cores. This compilation represents a complete synthetic sequence composed of optimal cores intervals obtained by correlation of Holes 798A, 798B, and 798C. Each core interval used and its correlative boundary to sub-and superjacent intervals are indicated, as well as the consecutively numbered dark-colored sections ( $0-225)$ and the character of the contact to the subjacent light-colored unit (sharp and well-defined or transitional). T stands for the presence of large burrow systems such as Thalassinoides and Planolites, which are indicative of well-oxygenated bottom waters. Low values in the gray curve adjacent to each sequence correspond to dark-colored intervals and high values to light-colored intervals. The gray values were measured directly from the core photos with an computer-connected video camera using an image-analysis program. 


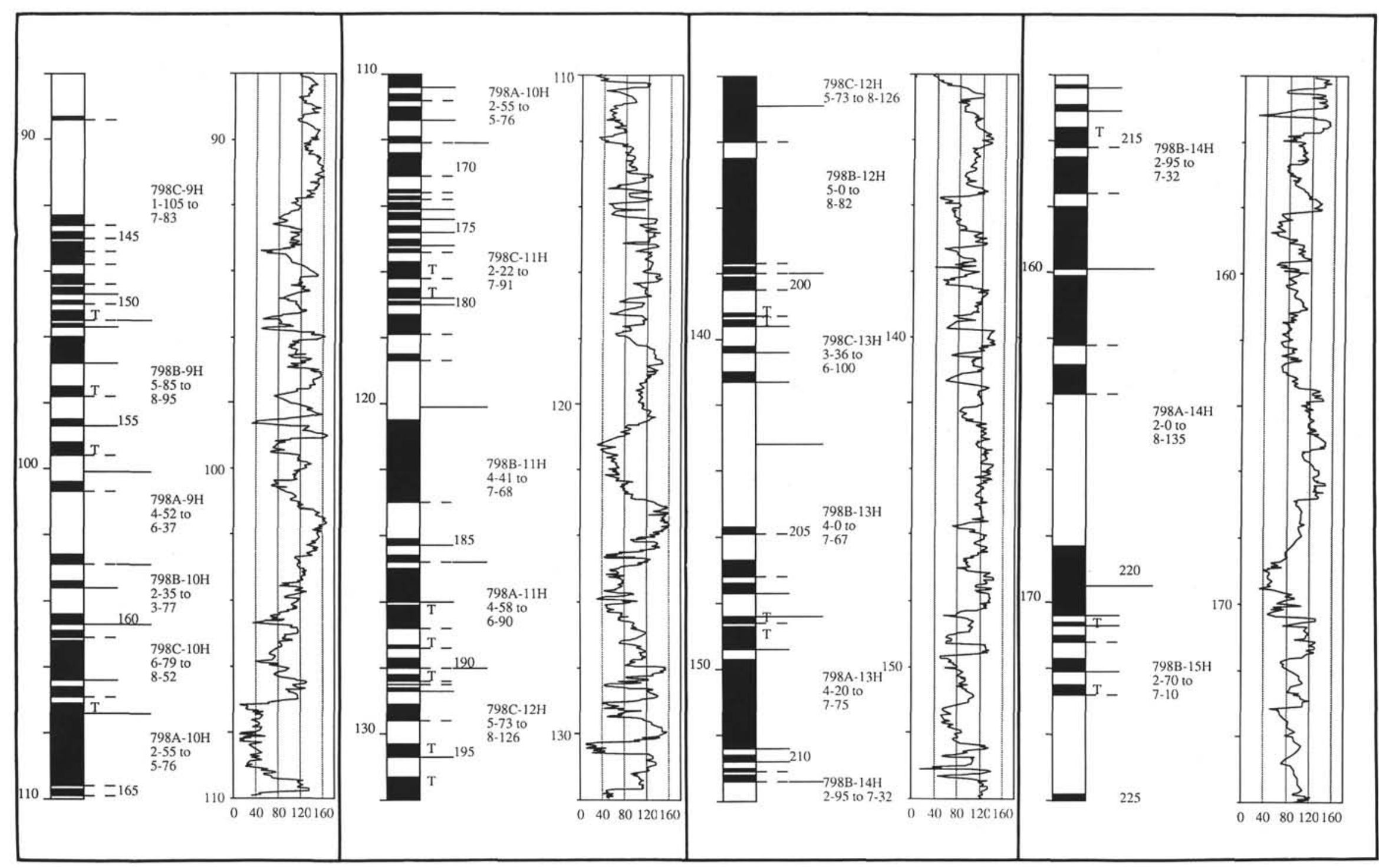

Figure 6 (continued). 


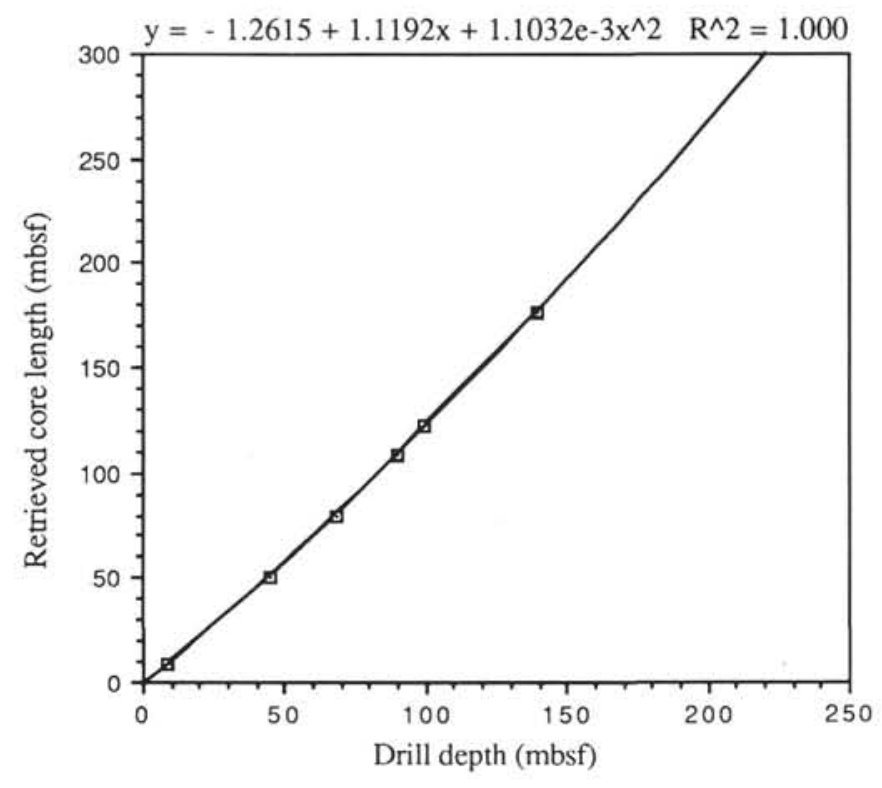

Figure 7. Plot of drilling depth of the upper part of Hole 128-798B vs. thickness of the decompacted and degassed sediments obtained by correlation of all three Site 798 APC-recovered holes. Data used are the depths for the Brunhes/ Matuyama boundary, upper and lower limit of the Jaramillo, besides some calculated depths. A best-fit polynomial plotted through these data allow extrapolation down to depths beyond the depth of the compiled sequence obtained by correlation $(=176 \mathrm{~m})$.

we performed a quantitative gray-value analysis on core photos of the upper Pleistocene part of Site 798.

\section{Characterization of the Second-Order Dark-Light Rhythms in Core 127-797B-6H}

The Pleistocene Core 127-797B-6H (Fig. 5) was selected by the Leg 127 shipboard scientists for a number of reasons. The core displays a well-defined set of second-order dark-light rhythms and is representative of the majority of the deep-water Pleistocene sediments recovered during Leg 127 . Furthermore, the core was subsampled intensively by the Leg 127 scientists for shore-based work, and this, together with the shipboard analyses, provided the framework for this contribution.

The core is dominated by homogeneous silty clays, which are medium light gray, pale green, and light bluish gray in color. These light-colored sediments alternate with a multitude of dark-colored, dusky green silty clays, some of which are well-laminated, some faintly laminated, and some lacking visible sedimentary structures. A large portion of the dark-colored rhythms have abrupt upper and lower color contacts; some grade into the overlying light-colored sequences.

The dark-colored units are generally enriched in organic carbon. A preliminary maximum value obtained for Core $127-797 \mathrm{~B}-6 \mathrm{H}$ is $2.1 \mathrm{wt} \%$, though values as high as $7.4 \mathrm{wt} \%$ have been recorded in similar dark-colored intervals in Core 127-797B-7H. In contrast, TOC values in the light-colored intervals average at about $1 \mathrm{wt} \%$.

Initial major element analysis (Table 2) shows that both the dark-, and light-colored units contain high levels of silica and aluminum and low levels of calcium. These values probably reflect the dominance of the siliceous biogenic input and a proximity to sources of terrestrial input.

Limited minor element analysis (Table 3 ) indicates that the darkcolored units are enriched in $\mathrm{As}, \mathrm{Ba}, \mathrm{Cu}, \mathrm{Mo}, \mathrm{Ni}, \mathrm{Pb}$, and $\mathrm{Zn}$, compared with the light-colored intervals which, in this particular case, are enriched in $\mathrm{Rb}, \mathrm{Sr}$, and $\mathrm{Zr}$.

Calcareous microfossils are not found in abundance throughout Hole 127-797B. Some areas are barren of these microfossils. The assemblage of planktonic foraminifers detected in 12 samples taken from Core 127-797B-6H consists of abundant sinistrally coiled Neogloboquadrina pachyderma and rare occurrences of dextrally coiled N. pachyderma, in addition to Globigerina bulloides, G. quinqueloba, and G. clarkei. Benthonic foraminifers include Globobulimina, Stainforthia, Cassidutina, and Fursenkoina. The assemblage is typical of subarctic waters. Diatoms dominate the deepwater microfossil assemblage in this core. In general, the well-laminated dark-colored units contain abundant (in some cases $>80 \%$ total sediment) diatom tests (Fig. 8). Thalassiothrix longissima, Thalassiosira sp., and the resting spores of Chaetoceros have been identified.

The GRAPE density for this core illustrates some of the physical properties of the dark-light rhythms (Fig. 5). The light-colored segments are higher in density (e.g., Sections $127-797 \mathrm{~B}-6 \mathrm{H}-4,0-14 \mathrm{~cm}$, and $22-41 \mathrm{~cm}$ ), whereas the dark-colored segments are either low in density (e.g., Sections $127-797 \mathrm{~B}-6 \mathrm{H}-2,2-10 \mathrm{~cm}$, and $31-40 \mathrm{~cm}$ ) or have a trend from high to low density across the interval (e.g., Sections 127-797B-6H-3, 90-102 cm, and 127-797B-6H-5, 82-90 cm).

\section{Characterization of the Second-Order Dark-Light Rhythm in Section 128-798B-10H-7}

The second-order dark-light rhythm in Section 128-798B-10H-7 was chosen as a typical example from Site 798 (Figs. 9 and 10; as mentioned before, this section was mislabeled as Section 128-798B$10 \mathrm{H}-4$ in the published core photos: cf. Ingle, Suyehiro, von Breymann, et al., 1990). Grain-size analyses display a fining-upward trend and physical-property data show an increased porosity and decreased wet-bulk and grain densities within the upper dark-colored interval

Table 2. XRF analyses of major elements (\%) in selected samples of Core 127-797B-6H.

\begin{tabular}{|c|c|c|c|c|c|c|c|c|c|c|c|c|}
\hline $\begin{array}{l}\text { Section, } \\
\text { interval }(\mathrm{cm})\end{array}$ & Rhythm & $\mathrm{Si}$ & $\mathrm{Al}$ & $\mathrm{Fe}$ & $\mathrm{Mn}$ & $\mathrm{Mg}$ & $\mathrm{Ca}$ & $\mathrm{Na}$ & K & $\mathrm{Ti}$ & $\mathrm{P}$ & Total \\
\hline $1,13-15$ & Light & 63.89 & 18.52 & 6.87 & 0.13 & 3.47 & 1.43 & 1.40 & 3.41 & 0.79 & 0.12 & 100.03 \\
\hline $2,138-140$ & Dark & 68.97 & 16.79 & 6.65 & 0.18 & 2.24 & 0.61 & 0.74 & 2.70 & 0.89 & 0.13 & 99.90 \\
\hline $3,132-134$ & Light & 63.90 & 17.98 & 7.34 & 0.21 & 3.63 & 1.13 & 0.96 & 3.42 & 0.98 & 0.12 & 99.67 \\
\hline $5,57-59$ & Dark & 62.81 & 17.85 & 7.90 & 0.69 & 3.21 & 1.91 & 0.84 & 2.91 & 0.70 & 0.15 & 98.97 \\
\hline $5,102-104$ & Light & 65.06 & 17.62 & 6.70 & 0.14 & 3.78 & 1.40 & 0.90 & 3.35 & 0.19 & 0.12 & 99.86 \\
\hline
\end{tabular}

Table 3. XRF analyses of minor elements (ppm) in selected samples of Core 127-797B-6H.

\begin{tabular}{llrrrrrrrrrrrr}
\hline $\begin{array}{l}\text { Section, } \\
\text { interval }(\mathrm{cm})\end{array}$ & Rhythm & $\mathrm{As}$ & $\mathrm{Ba}$ & $\mathrm{Cu}$ & $\mathrm{Mo}$ & $\mathrm{Ni}$ & $\mathrm{Pb}$ & $\mathrm{Rb}$ & $\mathrm{S}$ & $\mathrm{Sr}$ & $\mathrm{Y}$ & $\mathrm{Zn}$ & $\mathrm{Zr}$ \\
\hline $5,57-59$ & Dark & 34 & 1651 & 224 & 74 & 114 & 45 & 100 & 11242 & 130 & 30 & 216 & 141 \\
$5,102-104$ & Light & 13 & 566 & 112 & 0 & 74 & 32 & 138 & 6024 & 177 & 33 & 120 & 186 \\
\hline
\end{tabular}




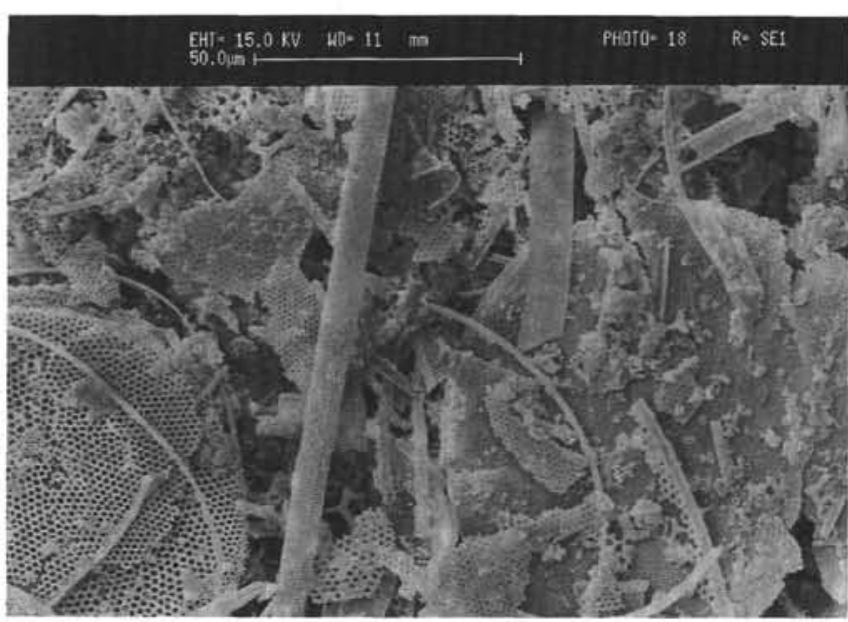

Figure 8. Scanning electron micrograph of Section 127-797B-6H-5, 57-59 cm.

(Figs. 9 and 10). Scanning electron micrographs indicate that the coarser particles within the dark-colored interval are well-preserved diatoms or foraminifers responsible for the shift in physical properties (Fig. 9). TOC values are elevated in the dark-colored interval and are just below $5 \mathrm{wt} \%$, in comparison to values of approximately $2 \mathrm{wt} \%$ within the light-colored intervals. The $\mathrm{C} / \mathrm{N}$ ratios and Rock-Eval Pyrolysis data suggest a predominantly marine source of the organic matter (Stein, 1991). Opal values increase within the dark-colored interval, as a result of increased contents of biosiliceous material. Mn, $\mathrm{Mg}, \mathrm{Fe}$, and $\mathrm{K}$ values are low in comparison to the light-coloredinterval. $\mathrm{CaCO}_{3}$ values are irregular and generally increase within the dark-colored interval, probably because of the presence of small laminae highly enriched in planktonic foraminifers. Illite and kaolinite values show a significant decrease toward the base of the dark interval, whereas chlorite is increased in value. Higher quartz and quartz/feldspar ratios within the light-colored interval reflect the upward increase in terrigenous material, and the $\mathrm{AI}$ values do also (Fig. 10).

\section{Geochemistry of Five Selected Second-Order Dark-Light Rhythms of Site 798}

Five well-defined, second-order dark-light rhythms were selected from the Pleistocene sediments of Hole 798C for geochemical evaluation (Table 4). X-ray fluorescence analyses of major and trace elements reveal the following trends:

1. Total $\mathrm{SiO}_{2}$ values generally show a upward increase (i.e., from the dark-colored upper unit to the light-colored lower unit). This is probably related to an upward increase in terrigenous minerals, which is more dominant than the observed upward decrease in biogenic silica.

2. Al values exhibit slightly increasing tendencies upward or remain equal. This may reflect the circumstances that the total upward increase in terrigenous material is caused mainly by an increase in the siliciclastic silt fraction and less by a increase in the clay fraction (in accordance with smear slide inspection).

3 . Iron contents covary with the $\mathrm{Al}$ values suggesting an interdependent relationship in which the bulk of the iron minerals is adsorbed on clay minerals. The ubiquitous presence off rhomboidal pyrite in the dark-colored intervals does not appear to reverse this trend.

4. Ca values vary inconsistently from rhythm to rhythm reflecting variations in calcareous nannoplankton and foraminifers (typically concentrated in discrete laminae of the dark-colored intervals).

5. The general upward increase of the transition metals $\mathrm{Zn}$ and $\mathrm{Ni}$ in the rhythms (exception is Core 128-798C-7H-6) may also be related to the increase in terrigenous input (e.g., Bralower and Thierstein,1987).

Total organic carbon invariably decreases upward in each selected rhythm, which is consistent with the higher amounts of organic matter generally observed in the dark-colored units.

Stable isotope data are still preliminary, and further systematic data collection is planned. A problem is posed by the general scarcity of planktonic foraminifers in the light-colored layers and of benthic foraminifers in the dark-colored units. The following observations are made (Table 4):

1. Samples from the rhythms in Sections 128-798C-IH-4 (7 in Fig. 6) and 128-798C-2H-3 (15 in Fig. 6) tie directly into the isotope curve for the upper part of Hole 128-798C and appear to correspond to isotope glacial stages 2 and 4, respectively (Dunbar et al., this volume). $\delta^{13} \mathrm{C}$ differences between benthic and planktonic foraminifers correspond to approximately $1 \%$ oo.

2. Samples from Section 128-798C-5H-2 (71 in Fig. 6) appear to be from a glacial/interglacial transitional interval with $\delta^{13} \mathrm{C}$ differences between benthic and planktonic foraminifers of approximately $2 \%$, which may indicate an increased stratification of the water column. This interval is attributed to the latest part of isotope stage 8 or the transition of stage 8 to stage 7 (Dunbar et al., this volume).

3. The rhythm in Section 128-798C-5H-7 appears to be from isotope stage 9 or the $9 / 8$ transition.

4. Benthic foraminifers in the rhythm in Section 128-798C-7H-6 (115 in Fig. 6) have enriched $\delta^{18} \mathrm{O}$ values, which are consistent with very cold and saline bottom waters (Dunbar et al., this volume).

5. The rhythm in Section 128-798C-12H-6 (195 in Fig. 6) also appears to be from a glacial interval with $\delta^{13} \mathrm{C}$ differences between benthic and planktonic foraminifers of approximately $1 \%$ o.

One important result of these preliminary stable-isotope measurements is that the dark-light rhythms in the Pleistocene sediments of Site 798 are not necessarily in phase with major changes in ice volume.

\section{Sedimentological Observations on Dark-Light Rhythms of Site 798}

In Figure 6, the character of the basal boundaries of the dark intervals present in the compiled sequence is indicated. It appears that approximately one third of the boundaries are sharp and well defined, whereas the remainder are transitional. Interestingly, internal laminations and fine beds within the dark-colored units (i.e., third-order rhythms) are generally confined to the sharply based ones, whereas the poorly defined dark intervals are more homogeneous internally and apparently more fine grained. Grimm and Kheradyar (this volume) did SEM surveys on selected third-order rhythms and proved their heterogeneous composition, which was attributed to short-term, probably seasonal, changes in nutrient levels and hydrodynamic regimes. The lenticular, well-bounded occurrence of some of these laminae demonstrated by Grimm and Kheradyar (this volume), the presence of low-angle truncations, as well as the occurrence of laminae containing abundant sponge spicules (Section 128-798C$7 \mathrm{H}-3,10-17 \mathrm{~cm}$ ) and Globigerina (in many sections) suggest that a significant portion of the laminae documents episodic hydrodynamic influences in terms of the residual enrichment of large particles by winnowing and possible reworking within gravity flows.

Burrows filled with light-colored sediments are common in the upper segments of the dark-colored intervals. The burrow systems consistently include Chondrites. Larger subvertical and subhorizontal burrows are generally difficult to identify; some resemble Planolites and Thalassinoides. These large burrow systems are used to identify conditions of relatively oxygen-rich bottom waters (indicated with a $\mathrm{T}$ in Fig. 6), in strong contrast to the dysaerobic conditions prevalent during deposition of the dark-colored sediments. 
Table 4. X-ray fluorescence measurements of major and trace elements, total organic carbon determinations (Carlo-Erba), and stable isotopes of selected intervals within five typical second-order dark-light rhythms from the Pleistocene of Hole 128-798C. ${ }^{a}$

\begin{tabular}{|c|c|c|c|c|c|c|c|c|c|c|c|c|c|}
\hline $\begin{array}{l}\text { Core, section } \\
\text { Interval }(\mathrm{cm})\end{array}$ & $\begin{array}{c}1 \mathrm{H}-4 \\
61-63\end{array}$ & $\begin{array}{c}\text { IH-4 } \\
67-69\end{array}$ & $\begin{array}{c}1 \mathrm{H}-4 \\
74-76\end{array}$ & $\begin{array}{c}1 \mathrm{H}-4 \\
86-88\end{array}$ & $\begin{array}{c}2 \mathrm{H}-3 \\
30-32\end{array}$ & $\begin{array}{c}2 \mathrm{H}-3 \\
45-47\end{array}$ & $\begin{array}{c}2 \mathrm{H}-3 \\
53-55\end{array}$ & $\begin{array}{c}2 \mathrm{H}-3 \\
62-64\end{array}$ & $\begin{array}{c}5 \mathrm{H}-2 \\
86-89\end{array}$ & $\begin{array}{c}5 \mathrm{H}-2 \\
99-101\end{array}$ & $\begin{array}{c}5 \mathrm{H}-2 \\
107-109\end{array}$ & $\begin{array}{c}5 \mathrm{H}-2 \\
116-118\end{array}$ & \\
\hline \multicolumn{14}{|l|}{$\begin{array}{l}\text { Major elements } \\
\text { (wt\%) }\end{array}$} \\
\hline $\mathrm{SiO}_{2}$ & 51.13 & 48.34 & 45.37 & 37.88 & 44.32 & 43.70 & 46.35 & 34.96 & 52.30 & 51.42 & 50.18 & 47.84 & \\
\hline $\mathrm{TiO}_{2}$ & 0.55 & 0.49 & 0.47 & 0.40 & 0.50 & 0.48 & 0.50 & 0.38 & 0.56 & 0.64 & 0.61 & 0.57 & \\
\hline $\mathrm{Al}_{2} \mathrm{O}_{3}$ & 13.48 & 12.55 & 11.86 & 10.33 & 11.78 & 11.84 & 12.56 & 9.49 & 14.12 & 15.20 & 14.96 & 14.40 & \\
\hline $\mathrm{Fe}_{2} \mathrm{O}_{3}$ & 5.27 & 4.39 & 3.85 & 3.48 & 4.24 & 3.98 & 4.02 & 2.97 & 4.50 & 4.98 & 5.25 & 4.36 & \\
\hline $\mathrm{MnO}$ & 0.05 & 0.06 & 0.04 & 0.03 & 0.03 & 0.03 & 0.02 & 0.02 & 0.04 & 0.03 & 0.03 & 0.03 & \\
\hline $\mathrm{MgO}$ & 2.50 & 2.31 & 2.26 & 2.05 & 2.35 & 2.25 & 2.30 & 1.96 & 2.25 & 2.47 & 2.37 & 2.27 & \\
\hline $\mathrm{CaO}$ & 5.35 & 7.26 & 8.58 & 14.38 & 11.41 & 10.02 & 7.44 & 16.77 & 6.22 & 3.58 & 2.12 & 5.70 & \\
\hline $\mathrm{Na}_{2} \mathrm{O}$ & 2.65 & 2.68 & 2.54 & 2.15 & 2.10 & 2.35 & 2.52 & 1.72 & 2.29 & 2.42 & 2.70 & 2.35 & \\
\hline $\mathrm{K}_{2} \mathrm{O}$ & 2.82 & 2.54 & 2.11 & 1.42 & 2.03 & 2.04 & 2.36 & 0.99 & 2.98 & 2.92 & 2.86 & 2.67 & \\
\hline $\mathrm{P}_{2} \mathrm{O}_{5}$ & 0.14 & 0.13 & 0.14 & 0.14 & 0.14 & 0.14 & 0.15 & 0.14 & 0.11 & 0.13 & 0.13 & 0.13 & \\
\hline $\mathrm{H}_{2} \mathrm{O}$ & 11.02 & 11.21 & 13.14 & 11.26 & 8.45 & 11.75 & 13.73 & 12.32 & 8.30 & 12.19 & 15.85 & 14.28 & \\
\hline $\mathrm{CO}_{2}$ & 3.30 & 4.73 & 5.83 & 10.63 & 8.43 & 6.86 & 4.99 & 12.76 & 4.14 & 1.90 & 0.40 & 3.34 & \\
\hline $\mathrm{Cr}_{2} \mathrm{O}_{3}$ & 0.02 & 0.02 & 0.02 & 0.02 & 0.02 & 0.02 & 0.02 & 0.01 & 0.02 & 0.02 & 0.02 & 0.02 & \\
\hline Total & 98.28 & 96.71 & 96.21 & 94.17 & 95.80 & 95.46 & 96.96 & 94.49 & 97.83 & 97.90 & 97.48 & 97.96 & \\
\hline $\begin{array}{l}\text { Trace elements } \\
(\mathrm{ppm})\end{array}$ & & & & & & & & & & & & & $\begin{array}{c}\text { Detection } \\
\text { limit }\end{array}$ \\
\hline $\mathrm{Nb}$ & 3 & 12 & 3 & 0 & 3 & 3 & 11 & 3 & 0 & 0 & 3 & 12 & 3.0 \\
\hline $\mathrm{Zr}$ & 81 & 92 & 58 & 73 & 81 & 69 & 95 & 46 & 101 & 109 & 97 & 116 & 4.0 \\
\hline $\mathbf{Y}$ & 0 & 21 & 0 & 13 & 0 & 0 & 18 & 0 & 7 & 0 & 0 & 26 & 4.0 \\
\hline $\mathrm{Sr}$ & 169 & 209 & 259 & 338 & 315 & 297 & 243 & 401 & 201 & 161 & 123 & 229 & 4.0 \\
\hline $\mathrm{U}$ & 0 & 1 & 0 & 0 & 0 & 0 & 1 & 0 & 0 & 0 & 0 & 10 & 1.6 \\
\hline $\mathrm{Rb}$ & 76 & 70 & 56 & 56 & 68 & 63 & 76 & 41 & 92 & 94 & 83 & 89 & 4.0 \\
\hline $\mathrm{Pb}$ & 0 & 15 & 0 & 0 & 0 & 0 & 14 & 0 & 0 & 0 & 0 & 16 & 6.0 \\
\hline $\mathrm{Zn}$ & 75 & 45 & 67 & 50 & 71 & 82 & 60 & 54 & 70 & 100 & 93 & 82 & 5.0 \\
\hline $\mathrm{Cu}$ & 0 & 7 & 0 & 0 & 5 & 13 & 12 & 0 & 4 & 16 & 15 & 16 & 7.0 \\
\hline $\mathrm{Ni}$ & 20 & 9 & 20 & 12 & 25 & 28 & 19 & 14 & 21 & 36 & 37 & 27 & 7.0 \\
\hline Co & 0 & 0 & 0 & 0 & 0 & 0 & 0 & 0 & 0 & 1 & 0 & 0 & 6.0 \\
\hline $\mathrm{Cr}$ & 67 & 24 & 84 & 39 & 64 & 71 & 50 & 65 & 76 & 96 & 85 & 63 & 10.0 \\
\hline V & 19 & 0 & 74 & 0 & 64 & 90 & 0 & 14 & 36 & 130 & 64 & 0 & 3.0 \\
\hline $\mathrm{Ce}$ & 0 & 0 & 0 & 0 & 0 & 0 & 0 & 0 & 0 & 18 & 0 & 0 & 23.0 \\
\hline $\mathrm{F}$ & 638 & 807 & 709 & 652 & 564 & 619 & 837 & 544 & 680 & 406 & 572 & 1011 & 11.0 \\
\hline $\mathrm{Ba}$ & 235 & 22 & 368 & 94 & 405 & 492 & 79 & 208 & 322 & 633 & 468 & 180 & 2.0 \\
\hline $\mathrm{La}$ & 0 & 0 & 0 & 0 & 0 & 0 & 0 & 0 & 0 & 19 & 7 & 0 & 12.0 \\
\hline $\mathrm{Sc}$ & 2 & 0 & 3 & 0 & 3 & 6 & 0 & 0 & 3 & 14 & 7 & 0 & .4 \\
\hline S & 9472 & 3870 & 7925 & 4821 & 7367 & 8774 & 4333 & 5913 & 7300 & 10639 & 13279 & 8029 & 16.0 \\
\hline Total & 10421 & 4790 & 9088 & 5775 & 8551 & 10052 & 5390 & 692 & 8412 & 11953 & 14413 & 9311 & \\
\hline TOC & 1.87 & 2.56 & 3.83 & 3.22 & 2.14 & 3.38 & 3.78 & 3.83 & 0.66 & 3.11 & 4.34 & 3.99 & \\
\hline \multicolumn{14}{|l|}{$\delta^{18} \mathrm{O}$} \\
\hline $\begin{array}{l}\text { Benthic } \\
\text { foraminifers }\end{array}$ & 4.21 & - & - & - & - & - & 4.28 & 4.34 & 4.63 & 4.31 & - & - & \\
\hline $\begin{array}{l}\text { Planktonic } \\
\text { foraminifers }\end{array}$ & - & - & 2.82 & 2.98 & - & - & - & 2.92 & - & 2.53 & - & - & \\
\hline \multicolumn{14}{|l|}{$\delta^{13} \mathrm{C}$} \\
\hline $\begin{array}{l}\text { Benthic } \\
\text { foraminifers }\end{array}$ & -1.52 & - & - & - & - & - & -1.34 & -0.31 & -1.53 & -1.33 & - & - & \\
\hline $\begin{array}{l}\text { Planktonic } \\
\text { foraminifers }\end{array}$ & - & - & -0.48 & 0.00 & - & - & - & -1.34 & - & -1.16 & - & - & \\
\hline
\end{tabular}

Note: Maximum relative errors in XRF analysis based mainly on calibration: oxides in weight percent: Total of $100= \pm 1 \%, 50= \pm 1 \%, 10= \pm 2 \%, 5= \pm 3 \%, 1= \pm 5 \%$.

Trace element concentrations in ppm: $1000= \pm 5 \%, 100= \pm 10 \%, 10= \pm 20 \%, 1= \pm 50 \%$.

Please note: Use $\mathrm{Cr}$ - and $\mathrm{Ni}$-values from trace element concentrations, corrected for mass absorption.

a Benthic foraminifer used for stable-isotope analysis is Uvigerina akitaensis, with the exception of Sections 128-798C-1H-4, 61-63 cm, and 128-798C-5H-2, 99-101 cm, where we used Angulogerina sp. Planktonic foraminifer is Globigerina bulloides with the exception of Section 128-798C-12H-7, 17-19 and 37-40 cm, where we used Neogloboquadrina pachyderma.

\section{Gray-Value Measurements of the Site 798-Compiled Synthetic Sequence and Time Series Analysis of the Dark-Colored Intervals}

Gray-value measurements of the compiled sequence of the Site 798 APC cores were performed through a detailed survey of the core photographs of the sedimentary segments indicated in Figure 6. This analysis was achieved with a computer-connected video camera using an image-analysis program. Coupled with the aforementioned depthage model, the gray-value measurements result in a high-resolution time series, in which patterns in the occurrence of the dark-light rhythms are quantified and the high-frequency changes in paleoceanographic conditions at Site 798 are mimicked for the last 1.26 m.y. (Fig. 6). The obvious advantage of this method is the ease by which a highly detailed record is obtained; in this case, one measurement was made each $2-5 \mathrm{~cm}$. A serious disadvantage is the difficulty in compensating for the unequal illumination of the cores during photographing. This was minimized after a long trial-and-error period of finding an illumination of the core photographs in a way that original inequalities are eliminated in the best possible way. Another difficulty is the possibility that gray values of the targeted sediments are caused by multiple independent variables (e.g., clay minerals, volcanogenic components, 
Table 4 (continued).

\begin{tabular}{|c|c|c|c|c|c|c|c|c|c|c|c|}
\hline $\begin{array}{l}\text { Core, section } \\
\text { Interval }(\mathrm{cm})\end{array}$ & $\begin{array}{c}5 \mathrm{H}-7 \\
35-38\end{array}$ & $\begin{array}{c}5 \mathrm{H}-7 \\
45-49\end{array}$ & $\begin{array}{c}5 \mathrm{H}-7 \\
55-58\end{array}$ & $\begin{array}{c}7 \mathrm{H}-6 \\
72-74\end{array}$ & $\begin{array}{r}7 \mathrm{H}-6 \\
89-91\end{array}$ & $\begin{array}{c}7 \mathrm{H}-6 \\
100-103\end{array}$ & $\begin{array}{c}7 \mathrm{H}-6 \\
110-113\end{array}$ & $\begin{array}{c}12 \mathrm{H}-7 \\
3-6\end{array}$ & $\begin{array}{l}12 \mathrm{H}-7 \\
17-19\end{array}$ & $\begin{array}{l}12 \mathrm{H}-7 \\
37-40\end{array}$ & \\
\hline \multicolumn{12}{|l|}{$\begin{array}{l}\text { Major elements } \\
(w t \%)\end{array}$} \\
\hline $\mathrm{SiO}_{2}$ & 40.68 & 31.20 & 35.73 & 51.75 & 49.75 & 51.73 & 51.40 & 51.96 & 45.45 & 49.87 & \\
\hline $\mathrm{TiO}_{2}$ & 0.48 & 0.36 & 0.40 & 0.64 & 0.62 & 0.60 & 0.62 & 0.58 & 0.38 & 0.28 & \\
\hline $\mathrm{Al}_{2} \mathrm{O}_{3}$ & 12.49 & 9.61 & 11.14 & 14.89 & 14.21 & 14.71 & 15.16 & 13.69 & 9.71 & 7.30 & \\
\hline $\mathrm{Fe}_{2} \mathrm{O}_{3}$ & 4.33 & 3.41 & 3.75 & 5.01 & 5,48 & 5.47 & 5.07 & 4.93 & 3.34 & 2.57 & \\
\hline $\mathrm{MnO}$ & 0.05 & 0.05 & 0.03 & 0.04 & 0.05 & 0.04 & 0.03 & 0.04 & 0.02 & 0.02 & \\
\hline $\mathrm{MgO}$ & 2.43 & 1.98 & 2.03 & 2.45 & 2.39 & 2.21 & 2.29 & 2.21 & 1.61 & 1.35 & \\
\hline $\mathrm{CaO}$ & 14.34 & 21.21 & 17.11 & 5.24 & 5.87 & 2.81 & 3.01 & 4.92 & 10.13 & 10.50 & \\
\hline $\mathrm{Na}_{2} \mathrm{O}$ & 1.35 & 1.36 & 1.53 & 2.20 & 2.09 & 2.54 & 2.44 & 2.22 & 2.07 & 2.12 & \\
\hline $\mathrm{K}_{2} \mathrm{O}$ & 1.70 & 0.77 & 1.33 & 2.90 & 2.79 & 2.74 & 2.90 & 2.72 & 1.75 & 1.49 & \\
\hline $\mathrm{P}_{2} \mathrm{O}_{5}$ & 0.15 & 0.15 & 0.14 & 0.13 & 0.13 & 0.13 & 0.13 & 0.13 & 0.14 & 0.14 & \\
\hline $\mathrm{H}_{2} \mathrm{O}$ & 7.38 & 7.96 & 7.42 & 9.96 & 10.79 & 13.37 & 13.86 & 11.06 & 11.09 & 11.15 & \\
\hline $\mathrm{CO}_{2}$ & 10.78 & 16.50 & 12.83 & 3.01 & 3.37 & 0.84 & 1.17 & 2.75 & 7.19 & 7.33 & \\
\hline $\mathrm{Cr}_{2} \mathrm{O}_{3}$ & 0.01 & 0.01 & 0.01 & 0.02 & 0.02 & 0.03 & 0.02 & 0.02 & 0.02 & 0.02 & \\
\hline Total & 96.17 & 94.57 & 93.45 & 98.24 & 97.56 & 97.22 & 98.10 & 97.23 & 92.90 & 94.14 & \\
\hline $\begin{array}{l}\text { Trace elements } \\
\text { (ppm) }\end{array}$ & & & & & & & & & & & $\begin{array}{c}\text { Detection } \\
\text { limit }\end{array}$ \\
\hline $\mathrm{Nb}$ & 0 & 3 & 3 & 0 & 0 & 7 & 15 & 3 & 3 & 0 & 3.0 \\
\hline $\mathrm{Zr}$ & 84 & 61 & 63 & 130 & 103 & 113 & 128 & 89 & 50 & 54 & 4.0 \\
\hline $\mathrm{Y}$ & 2 & 0 & 0 & 3 & 2 & 15 & 24 & 0 & 0 & 3 & 4.0 \\
\hline $\mathrm{Sr}$ & 397 & 572 & 461 & 187 & 201 & 157 & 166 & 183 & 304 & 300 & 4.0 \\
\hline $\mathrm{U}$ & 0 & 0 & 0 & 0 & 0 & 0 & 5 & 0 & 0 & 0 & 1.6 \\
\hline $\mathrm{Rb}$ & 82 & 51 & 62 & 95 & 85 & 89 & 100 & 82 & 43 & 34 & 4.0 \\
\hline Th & 0 & 0 & 0 & 0 & 0 & 0 & 1 & 0 & 0 & 0 & 6.0 \\
\hline $\mathrm{Pb}$ & 0 & 0 & 0 & 0 & 0 & 9 & 21 & 0 & 0 & 0 & 6.0 \\
\hline $\mathrm{Zn}$ & 69 & 52 & 53 & 90 & 79 & 80 & 92 & 82 & 64 & 31 & 5.0 \\
\hline $\mathrm{Cu}$ & 10 & 5 & 12 & 7 & 5 & 10 & 22 & 8 & 6 & 4 & 7.0 \\
\hline $\mathrm{Ni}$ & 25 & 20 & 17 & 28 & 25 & 29 & 35 & 30 & 30 & 11 & 7.0 \\
\hline $\mathrm{Co}$ & 4 & 3 & 0 & 0 & 0 & 0 & 0 & 0 & 0 & 0 & 6.0 \\
\hline $\mathrm{Cr}$ & 55 & 30 & 37 & 81 & 79 & 89 & 69 & 72 & 107 & 30 & 0.0 \\
\hline V & 106 & 54 & 2 & 105 & 63 & 31 & 13 & 91 & 55 & 0 & 3.0 \\
\hline $\mathrm{Ce}$ & 0 & 0 & 0 & 7 & 0 & 0 & 0 & 0 & 0 & 0 & 23.0 \\
\hline F & 1044 & 1118 & 505 & 609 & 680 & 797 & 1020 & 450 & 411 & 837 & 11.0 \\
\hline $\mathrm{Ba}$ & 525 & 422 & 240 & 430 & 366 & 290 & 227 & 466 & 457 & 40 & 2.0 \\
\hline $\mathrm{La}$ & 0 & 0 & 0 & 12 & 3 & 4 & 2 & 7 & 0 & 0 & 12.0 \\
\hline $\mathrm{Sc}$ & 7 & 0 & 0 & 10 & 6 & 5 & 3 & 9 & 2 & 0 & .4 \\
\hline$S$ & 7122 & 7887 & 7087 & 8789 & 13191 & 13221 & 10794 & 11008 & 10267 & 3296 & 16.0 \\
\hline Total & 19168 & 14298 & 17257 & 15839 & 22916 & 24454 & 17504 & 19049 & 19777 & 16154 & \\
\hline TOC & 0.95 & 1.35 & 1.79 & 1.47 & 1.65 & 2.82 & 3.65 & 2.03 & 3.44 & 3.29 & \\
\hline \multicolumn{12}{|l|}{$\delta^{18} \mathrm{O}$} \\
\hline $\begin{array}{l}\text { Benthic } \\
\text { foraminifers }\end{array}$ & 3.42 & - & - & 5.23 & 4.83 & 4.56 & - & 4.49 & - & - & \\
\hline $\begin{array}{l}\text { Planktonic } \\
\text { foraminifers }\end{array}$ & 2.25 & 1.80 & 1.30 & - & - & - & - & - & 1.99 & 2.04 & \\
\hline \multicolumn{12}{|l|}{$\delta^{13} \mathrm{C}$} \\
\hline $\begin{array}{l}\text { Benthic } \\
\text { foraminifers }\end{array}$ & -2.60 & - & - & -1.54 & -1.55 & -1.93 & - & -1.27 & - & - & \\
\hline $\begin{array}{l}\text { Planktonic } \\
\text { foraminifers }\end{array}$ & -0.83 & -0.72 & 0.86 & - & - & - & - & - & 0.15 & -0.15 & \\
\hline
\end{tabular}

biogenic carbonates). This is certainly relevant in our case; the light-colored units contain, for example, variable amounts of calcareous nannofossils and silt-size detrital components, both influencing the brightness of the sediments (Ingle, Suyehiro, von Breymann, et al., 1990). On the other hand, the dark units are all characterized by relatively high amounts of organic matter; the changes from light to dark, to which a paleoceanographic significance is attributed, are well captured in the image analysis. The common presence of desiccation cracks in the cores, which appear as black fissures on the core photographs, introduces a further problem for image analysis. We circumvented this problem by point-measuring the gray values in the areas between the present desiccation cracks.

A time-series analysis was performed on the gray values, after applying the aforementioned age-depth model to the measured sequences. The analysis was performed using the methods described in Park et al. (1987) and Thomson (1982). Results of this analysis corroborate the results of the crude visual inspection of the correlated sequence. Gray-value variance is concentrated at periods of approximately $103,800,41,500,27,100,18,900,16,400,12,700$, and particularly $10,500 \mathrm{yr}$ (Fig. 11). The first two frequencies correlate precisely to the eccentricity and obliquity frequencies, and are attributed to first-order rhythms. The significant frequency of $10,500 \mathrm{yr}$ is attributed to the second-order rhythms; it corresponds to the half of the precession frequency and its importance is explained below.

\section{Dark-Light Rhythms at Site 799}

The Pleistocene hemipelagic sequence at Site 799 is punctuated by numerous intercalations of reworked sediments (slumps, slides, and turbidites). This aspect and the presence of just one APC-cored hole made it difficult to establish a reliable time record for the dark-light rhythms observed. The very dark, and probably most 

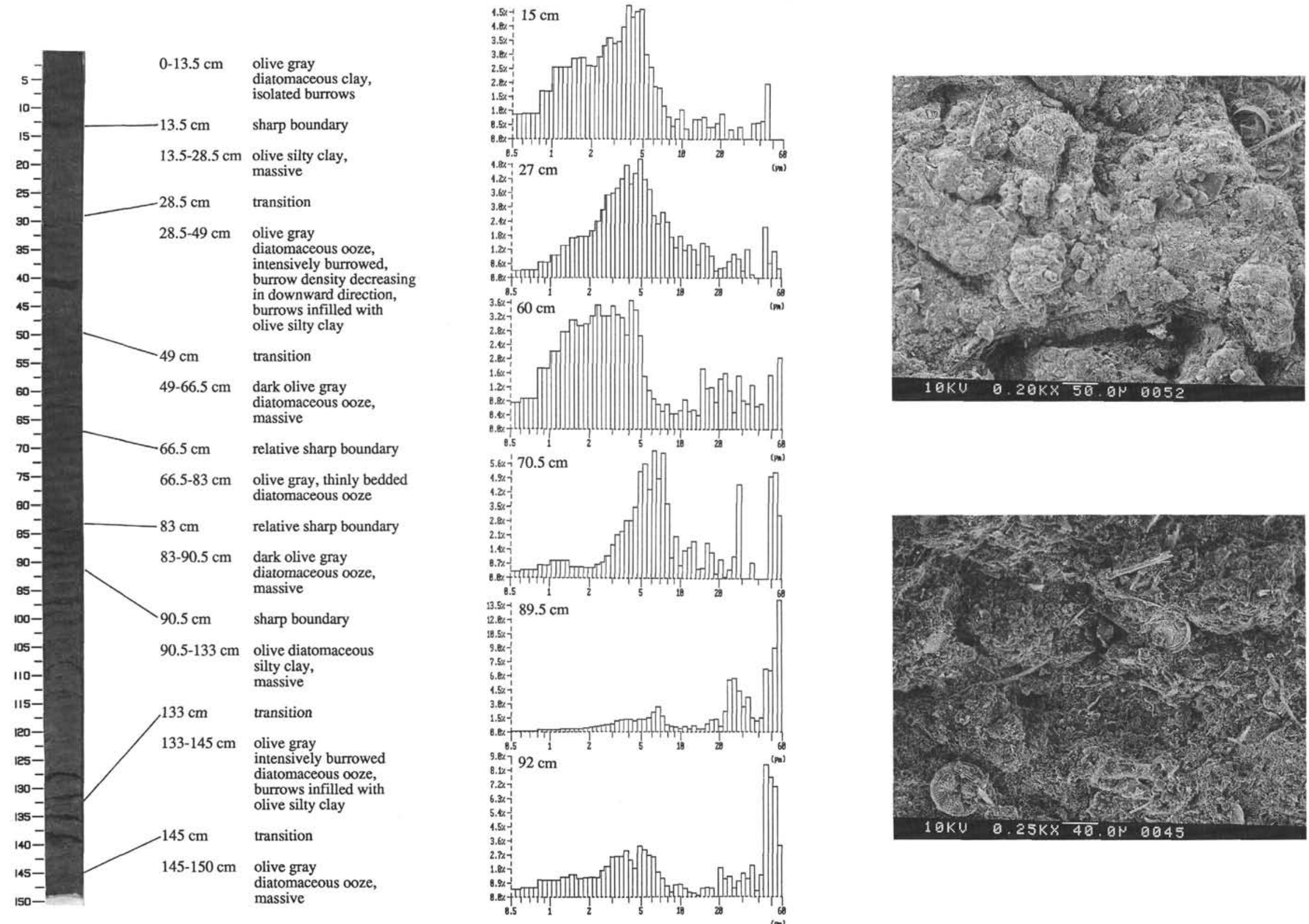

Figure 9. Dark-light rhythms in Section 128-798B-10H-7, 91.65-93.15 mbsf (lower Pleistocene). Grain-size analyses were performed with a computerized laser inspection system. 

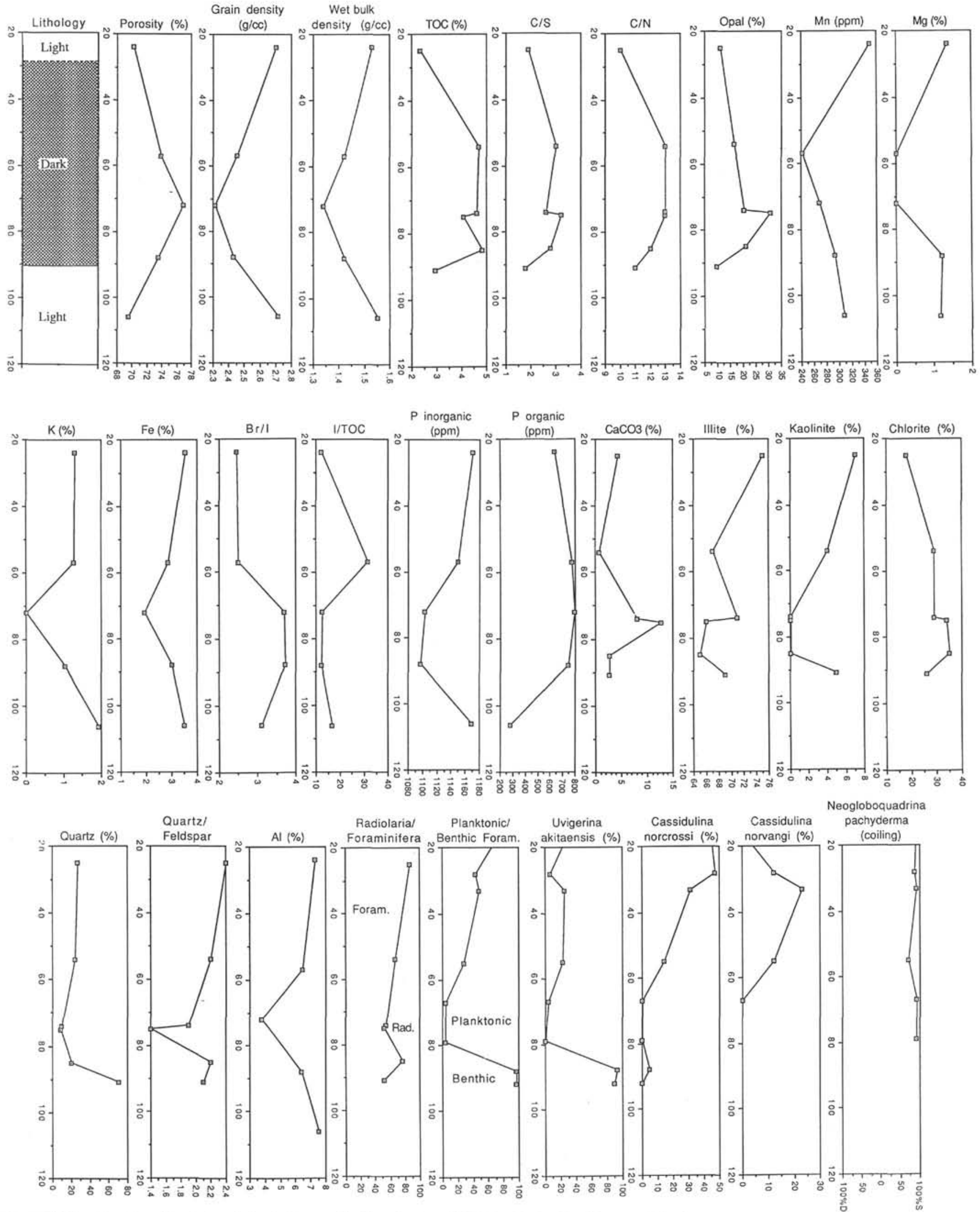

Figure 10. A series of geochemical and physical properties from Section 128-798B-10H-7, 20-120 cm (cf. Fig. 9). 
organic-rich, intervals at Site 799 (maximum shipboard total organic carbon value is $5.6 \%$; Ingle, Suyehiro, von Breymann, et al., 1990) exhibit consistent internal laminations and a sharp and well-defined base, whereas the top may be transitional. The somewhat lighter colored dark intervals are less well-defined and also appear to be finer grained than their very dark counterparts.

In general, the dark-colored intervals at Site 799 appear to be thinner and more fragmented, in comparison to those at Site 798, and resemble those of Site 797. In addition, most of the dark units at both Sites 797 and 799 lack the invading bioturbation in their top segments, which is characteristic for those at Site 798. The meaning of this is unclear yet, but may be related to the greater depth of Sites 797 and 799 during deposition of the Pleistocene dark-light rhythms.

\section{PALEOCEANOGRAPHIC AND CLIMATIC SIGNIFICANCE OF THE DARK-LIGHT RHYTHMS, A PRELIMINARY INTERPRETATION}

The presence of winnowed and Globigerina- and sponge spiculeenriched laminae and sharp and well-defined bases in many of the dark-colored intervals suggests that the paleoceanographic conditions during deposition of these intervals were characterized by intensified hydrodynamics rather than stagnation, and that these conditions must have changed in a very rapid fashion (in less than one to a few years) during certain times. Furthermore, the onset of deposition of a darkcolored interval may have corresponded to a decrease in oxygen contents of bottom waters. Oxygen depletion is indicated by the generally increased values of preserved organic carbon, the consistent absence of bioturbation, and the enlarged $\mathrm{Br} / \mathrm{I}$ and lowered I/TOC ratios within the dark interval of Section 128-798B-I0H-7 (Fig. 8; Price and Calvert 1973; Kennedy and Elderfield 1987a, 1987b). In addition, preliminary investigations of the diatoms preserved in Section 128-798B-10 H-7 show that some dark laminae contain abundant resting spores of the genus Chaetoceros, which is generally taken as indication of nutrient-rich waters (Burckle, this volume; Grimm and Kheradyar, this volume). Similarly, the increased $\mathrm{Cu}$ and $\mathrm{Ba}$ values in Core 127-797B-6H also imply high nutrient levels. These data indicate increased productivity levels and partly intensified hydrodynamics during deposition of the dark-colored and organic-rich sediments (cf. Stein, 1991).

The light-colored units are rich in terrigenous material, which may be wind-derived (e.g., at Site 798, which is located on a submarine high lacking major marine detrital influxes).

Using the previously described time model, the preliminary isotope data, and the spectral analysis of the gray-value time series, the dark units within the dark-light rhythms at Site 798 appear not to be temporally bound to either glacial or interglacial periods, but seem to be more directly related to the obliquity and eccentricity cycles for the first-order rhythms, to the precession cycle for the second-order rhythms, and the annual cycle for the third-order rhythms.

The origin of the first- and second-order dark- and light-colored units is, therefore, to be sought in Milankovitch-related climatic changes with the dark-colored sediments corresponding to periods of poorly ventilated bottom waters and increased primary production and the light-colored sediments to periods of increased eolian input. One possible climate-linked mechanism proposed by Japanese researchers is the shallowing of the Tsushima sill depth through sea-level fall and subsequent deflection of the Tsushima Current system in a northeastern direction along the east coast of Honshu, which then led to suppressed thermohaline convection and oxygen deficiency within the Japan Sea (Ujiié and Ichikura, 1973; Ichikura and Ujiié, 1976; Matoba, 1984; Oba et al., 1991).

A second possible mechanism is the formation of a major ice lid in the northern parts of the Japan Sea and termination of cold-water formation. The discovery of sea-ice diatoms in upper Pliocene and lower Pleistocene sediments confirms the episodic presence of ice caps (Brunner et al., 1990).
A third possibility is the major influx of fresh waters into the Japan Sea via the Tsushima Strait during lowered sea levels and the deviation of Yellow River branches into the Japan Sea (Burckle, this volume). A major input of low salinity waters into the Japan Sea may have had the effect that winter cooling was insufficient to raise the density of surface waters enough for deep-water formation.

A combination of these three proposed mechanisms may have been involved in the formation of the first-order dark-light rhythms. However, they are essentially dependent on the development of ice caps and corresponding major sea-level changes, and do not, therefore, account for the observation that the appearance of dark-light rhythms is not in phase with the periods of major glaciation (approximated, e.g., by the $\delta^{18} \mathrm{O}$ record).

The second-order dark-light rhythms show a dominant frequency of $10,500 \mathrm{yr}$, which is well-expressed in the spectral analysis (Fig. 11). This frequency is not uncommon in oceanic climate records and considered to represent half of the precession cycle. It is probably related to the interaction of perihelion with the overhead passage of the sun at the equinoxes which generates a frequency half the precessional one (Berger, 1988; Heinrich, 1988; Short et al., 1991). This precessional component may link the origin of the second-order rhythms to the computed record of variations in solar insolation, which is strongly dominated by the precessional record (Berger, 1978, 1989; Berger et al., 1990). This record is used as a proxy for the reconstruction of the intensity of past summer monsoonal activity (Kutzbach and Street-Perrott, 1985; Prell and Kutzbach, 1987; Clemens et al., 1991). We speculate, for this reason, that the secondorder rhythms have formed in response to variations in summer monsoonal activity. Similarly, the origin of the third order rhythms might also be related to periods of increased seasonal insolation contrast and strong summer monsoonal activity (cf. Grimm and Kheradyar, this volume). In addition, this may also be valid for the first-order rhythms, which may have formed in phase with long-term variations in monsoonal strength in linking the first-, second-, and third-order rhythms to a similar mechanism, we may obtain an explanation for the observed similarity in the geometrical patterns of the rhythms. Also the rapidness of change observed in many dark-

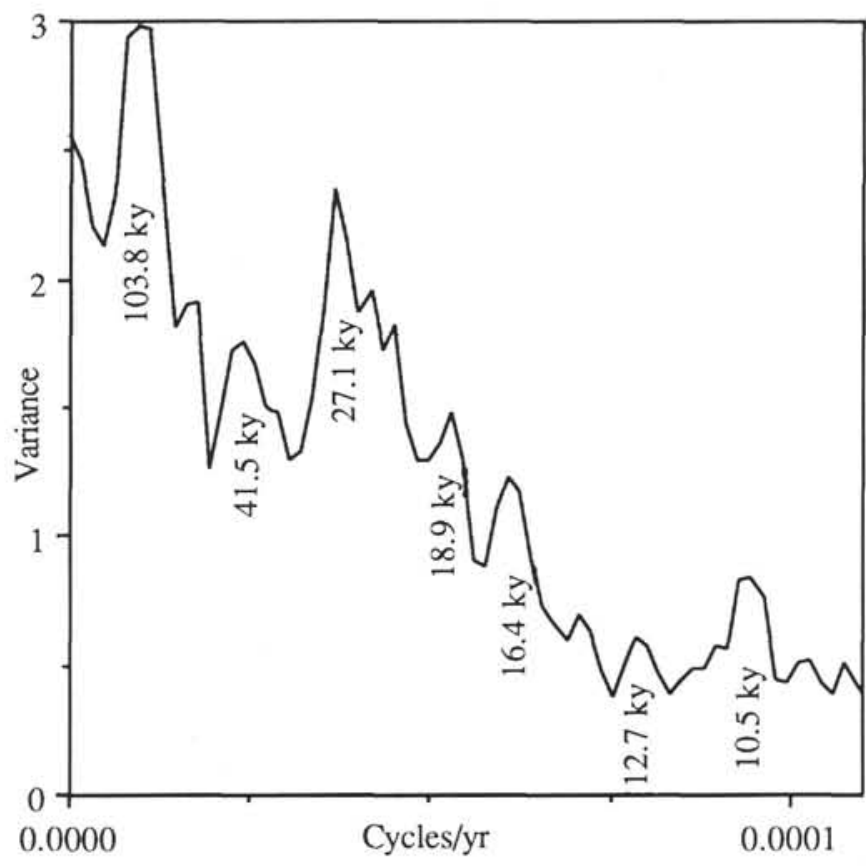

Figure 11. Gray-value power spectra of the synthetic correlated sequence $(0-1.26$ m.y. ago) at Site 798 (cf. Fig. 6). 
light rhythms may be explained by the rapid change in monsoonal activity, possible on a short-term, seasonal, base and on a longer-term base in phase with the orbital frequencies.

However, the monsoonal explanation is still speculative and founded solely on the presence of a strong precessional signal and on similarities of the different geometrical hierarchies. Further research is needed for scientific validation.

\section{DISCUSSION AND CONCLUSIONS}

Recent studies have shown that time series used as proxy for Pleistocene climate variations in middle and even high latitudes may show a strong precessional component, in addition to the eccentricity and obliquity orbital parameters (Clemens et al., 1991; Crowley, 1991). Time series obtained by gray-value measurements from darklight rhythms in sediments of the Japan Sea confirm this observation: Although spectral analysis suggests significant variance in the frequencies of the eccentricity (103,000 yr.) and obliquity (41,000 yr.), the depth-age model based on the paleomagnetic record and preliminary stable-isotope analysis shows that the climate record in sediments of late Pleistocene age (0-1.26 m.y. ago) is not in phase with variations in ice volume. The spectral analysis of the gray-value record shows strong variance around $10,500 \mathrm{yr}$, a frequency which is approximately half the precession frequency. This frequency is usually known from low-latitude time series and relates to the computed record of variations in solar radiation. In turn, this record is used as a proxy for fluctuations in monsoonal activity. The origin of the darklight rhythms may, therefore, be linked to the intensity of monsoonal activity. If this is the case, it remains unclear how monsoonal activity might influence the physical properties of the Japan Sea. We speculate that intense monsoonal activity accelerates surface-water mixing and increases the availability of nutrients to the surface waters. This might lead to short episodes of increased productivity, which is subsequently registered through the formation of the dark-colored units (cf. Grimm and Kheradyar, this volume). The light-colored units, on the other hand, document increased eolian input, which may be related to the so-called Japan Sea "winter monsoon," characterized by strong northwestern winds (Suzuki, 1962: Shitara, 1969). These winds import eolian detritus from the Asian mainland (Hovan et al., 1989; deMenocal et al., this volume). If these assumptions are valid, then the Pleistocene darklight cycles reflect the relative importance of summer and winter monsoonal activity during the Pleistocene.

\section{ACKNOWLEDGMENTS}

The first author acknowledges the financial support of the Swiss National Science Foundation for shipboard participation and subsequent shore-based investigations. A. Cramp and J. McEvoy are grateful to the U.K. Natural Environment Research Council for financial support. Daniel Müller (Zürich), Poppe de Boer (Utrecht), Judith Totman Parrish (Tucson), Ken Pisciotto (London), Gerhard Einsele (Tübingen), William Ruddiman (Palisades), and John Barron (Menlo Park) provided helpful reviews of earlier drafts. Tim Herbert (La Jolla) is thanked for the generous access to his time-series analysis program. Martin Tuchschmid (Zürich) assisted with sample preparation for X-ray fluorescence analyses. Discussions with Frank Niessen (Zürich) very much helped to improve our understanding of the data presented here.

\section{REFERENCES}

Arai, F., Oba, T., Kitazato, H., Horibe, Y., and Machida, H., 1981. Late Quaternary tephrochronology and paleo-oceanography of the sediments of the Japan Sea. Quat. Res. (Tokyo), 20:209-230. (in Japanese with English abstract)

Barash, M. S., 1986. The paleo-oceanographic conditions of formation of the late Miocene phosphorite horizon of the north Yamato Rise (Sea of Japan). Oceanology, 26:721-724.
Berger, A. L., 1978. Long-term variations of caloric insolation resulting from the earth's orbital elements. Quat. Res., 9:139-167.

1988. Milankovitch theory and climate. Rev. Geophys., $25: 624-657$

1989. The spectral characteristics of pre-Quaternary climatic records: an example of the relationship between the astronomical theory and geosciences. In Berger, A. (Ed.), Climate and Geo-Sciences: Dordrecht (Kluwer), 47-76.

Bralower. T. J., and Thierstein, H. R., 1987. Organic carbon and metal accumulation rates in Holocene and mid-Cretaceous sediments: palaeoceanographic significance. In Brooks, J., and Fleet, A. J. (Eds.), Marine Petroleum Source Rocks. Geol. Soc. Spec. Publ. London, 26:345-369.

Brunner, C. A., Rahman, A., Koizumi, I., White, L. D., Alexandrovich, J. M., and ODPLeg 127 Scientific Party, 1990. Major climatic changes in surface waters of the Japan Sea since the early middle Miocene. Eos, 71:118.

Chough, S. K., 1984. Fine-grained turbidites and associated mass-flow deposits in the Ulleung (Tshushima) back-arc basin, East Sea (Sea of Japan). In Stow, D.A.V., and Piper, D.J.W. (Eds.), Fine-grained Sediments: DeepWater Processes and Facies. Geol. Soc. Spec. Publ. London, 15:185-196.

Clemens, S., Prell, W., Murray, D., Shimmield, G., and Weedon, G., 1991. Forcing mechanisms of the Indian Ocean monsoon. Nature, 353:720-725. Crowley, T. J., 1991. Ice-age methane variations. Nature, 353:122-123.

Föllmi, K. B., Alexandrovich, J., Brunner, C. A., Burckle, L. H., Charvet, J., Cramp, A., deMenocal, P., Dunbar, R., Grimm, K. A., Holler, P., Ingle, J. C., Isaacs, C., Kheradyar, T., Koizumi, I., Matsumoto, R., Nobes, D., Pisciotto, K., Rahman, A., Stein, R., Tada, R., von Breymann, M., and Scientific Parties, Legs 127 and 128, 1990. Paleoceanographic implications from high-frequency dark/light rhythms in the Sea of Japan (ODP Legs 127 and 128). AAPG Bull., 74:973. (Abstract)

Heinrich, H., 1988. Origin and consequences of cyclic ice rafting in the northeast Atlantic Ocean during the past 130,000 years. Quat. Res., 29:142-152.

Honza, E. (Ed.), 1979. Geological investigation of the Japan Sea 1978 (GH-78 cruise). Geol. Surv. Jpn., Cruise Report, 13.

Hovan, S. A., Rea, D. K., Pisias, N. G., and Shackleton, N. J., 1989. A direct link between the China loess and marine delta $\delta^{18} \mathrm{O}$ records: aeolian flux to the North Pacific. Nature, 340:296-298.

Ichikura, M., and Ujiié, H., 1976. Lithology and planktonic foraminifera of the Sea of Japan piston cores. Bull. Nat. Mus., Ser. C (Geol.), 2:151-176.

Imbrie, J., Hays, J. D., Martinson, D. G., McIntire, A., Mix, A. C., Morley, J. J., Pisias, N. G., Prell, W. L., and Shackleton, N. J., 1984. The orbital theory of Pleistocene climate: support from a revised chronology of the marine delta $\delta^{18}$ O record. In Berger, A. L., Imbrie, J., Hays, J. D., Kukla, G., and Saltzman, B. (Eds.), Milankovitch and Climate (Pt. 1): Dordrecht (Reidel), 269-305.

Ingle, J. C., Jr., Suyehiro, K., von Breymann, M. T., et al., 1990. Proc. ODP, Init. Repts., 128: College Station, TX (Ocean Drilling Program).

Kennedy, H. A., and Elderfield, J., 1987a. Iodine diagenesis in pelagic deep sea sediments. Geochim. Cosmochim. Acta, 51:2489-2504.

$-1987 \mathrm{~b}$. Iodine diagenesis in non-pelagic deep sea sediments. Geochim. Cosmochim. Acta, 51:2505-2514.

Kobayashi, K., 1985. Sea of Japan and Okinawa Trough. In Nairn, A.E.M., Stehli, F., and Uyeda, S. (Eds.), The Ocean Basins and Margins (Vol. 7A): The Pacific Ocean: New York (Plenum), 419-458.

Kutzbach, J. E., and Street-Perrott, F. A., 1985. Milankovitch forcing of fluctuations in the level of tropical lakes from 18 to 0 kyr BP. Nature, 317:130-134.

Leg 127 and Leg 128 Scientific Parties, 1990. Evolution of the Japan Sea. Nature, 346:18-20.

Leg 127 Scientific Party, 1989. Exploring the Japan Sea. Geotimes, 34:19-21. Leg 128 Scientific Party, 1990. ODP in the Japan Sea. Geotimes, 35:25-27.

Matoba, Y., 1984. Paleoenvironments of the Sea of Japan. In Oertli, H. J. (Ed.), Benthos '83; 2nd Int. Symp. Benthic Foraminifera, 409-414.

Niino, H., Emery, K. O., and Kim, C. M., 1969. Organic carbon in sediments of Japan Sea. J. Sediment. Petrol., 39:1390-1398.

Oba, T., 1983. Paleoenvironment of the Sea of Japan since the last glacial epoch. Gekkan Chikyu, 5:38-46. (in Japanese)

Oba, T., Kato, M., Kitazato, H., Koizumi, I., Omura, A., Sakai, T., and Takayama, T., 1991. Paleoenvironmental changes in the Japan Sea during the last 85,000 years. Paleoceanography, 6:499-518.

Park, J., Lindberg, C. R., and Vernon, F. L., III, 1987. Multitaper spectral analysis of high frequency seismograms. J. Geophys. Res., 92:12675-12684.

Prell, W. L., Imbrie, J., Martinson, D. G., Morley, J. J., Pisias, N. G., Shackleton, N. J., and Streeter, H. F., 1986. Graphic correlation of oxygen isotope stratigraphy application to the late Quaternary. Paleoceanography, 1:137-162. 
Prell, W. L., and Kutzbach, J. E., 1987. Monsoon variability over the past 150,000 years. J. Geophys. Res., 92:8411-8425.

Price, N. B., and Calvert, S. E., 1973. The geochemistry of iodine in oxidized and reduced recent marine sediments. Geochim. Cosmochim. Acta, 37:2149-2158.

Ruddiman, W. F., Raymo, M. E., Martinson, D. G., Clement, B. M., and Beckman, J., 1989. Pleistocene evolution: Northern hemisphere ice sheets and North Atlantic Ocean. Paleoceanography, 4:353-412.

Shitara, H., 1969. The air temperature fluctuation in Asia in winter viewed from the distribution of deviation sign. Jpn. Progr. Climatol., 1969:28-25.

Short, D. A., Mengel, J. G., Crowley, T. J., Hyde, W. T., and North, G. R., 1991. Filtering of Milankovitch Cycles by earth's geography. Quat. Res., 35:157-173.

Stein, R., 1991. Accumulation of organic carbon in marine sediments. Results from the Deep Sea Drilling Project/Ocean Drilling Program (DSDP/ODP). Lecture Notes in Earth Sciences, 34: Heidelberg (Springer), 277 p.
Suzuki, H., 1962. Klassifikation der Klimate von Japan in der Gegenwart und der letzten Eiszeit. Jpn. Progr. Climatol., 1962:74-92.

Tamaki, K., 1988. Geological structure of the Japan Sea and its tectonic implications. Chishitsu Chosasho Geppo, 39:269-365.

Tamaki, K., Pisciotto, K., Allan, J., et al., 1990. Proc. ODP, Init. Repts. 127: College Station, TX (Ocean Drilling Program).

Thomson, D. J., 1982. Spectrum estimation and harmonic analysis. Proc. IEEE, 70:1055-1096.

Ujiié, H., and Ichikura, M., 1973. Holocene to uppermost Pleistocene planktonic foraminifers in a piston core from off San'n district, Sea of Japan. Trans. Proc. Palaeontol. Soc. Jpn., 91:137-150.

Date of initial receipt: 25 March 1991

Date of acceptance: 9 December 1991

Ms 127/128B-159 